European Journal of Turkish Studies

Social Sciences on Contemporary Turkey

5 | 2006

THEMATIC ISSUE

Power, ideology, knowledge - deconstructing Kurdish

Studies

\title{
Knowledge, ideology and power. Deconstructing Kurdish Studies
}

Clémence Scalbert-Yücel and Marie Le Ray

\section{OpenEdition \\ Journals}

Electronic version

URL: https://journals.openedition.org/ejts/777

DOI: 10.4000/ejts. 777

ISSN: $1773-0546$

Publisher

EJTS

Electronic reference

Clémence Scalbert-Yücel and Marie Le Ray, "Knowledge, ideology and power. Deconstructing Kurdish Studies", European Journal of Turkish Studies [Online], 5 | 2006, Online since 05 March 2015, connection on 10 December 2021. URL: http://journals.openedition.org/ejts/777 ; DOI: https://doi.org/10.4000/ ejts. 777 


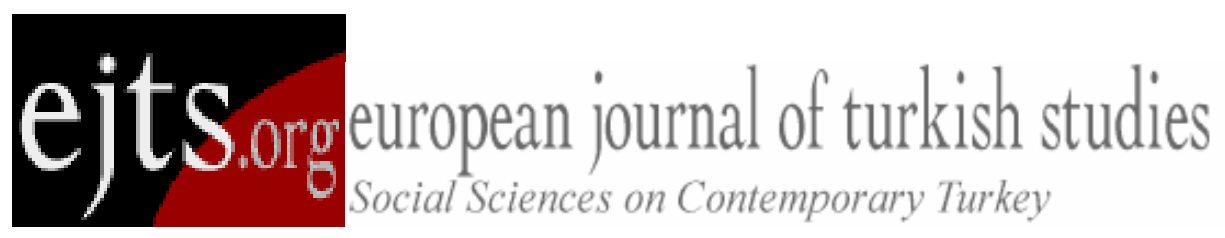

Scalbert-Yücel, Clémence and Ray, Marie Le (2006) 'Knowledge, ideology and power. Deconstructing Kurdish Studies', European Journal of Turkish Studies, Thematic Issue N5 , Power, ideology, knowledge deconstructing Kurdish Studies, URL : http://www.ejts.org/document $777 . \mathrm{html}$ To quote a passage, use paragraph (§).

\section{Knowledge, ideology and power. Deconstructing Kurdish Studies}

Clémence Scalbert Yücel, Marie Le Ray 
Scalbert-Yücel, Clémence and Ray, Marie Le (2006) 'Knowledge, ideology and power. Deconstructing Kurdish Studies', European Journal of Turkish Studies, Thematic Issue N5, Power, ideology, knowledge deconstructing Kurdish Studies, URL : http://www.ejts.org/document777.html To quote a passage, use paragraph (§).

Update: 14. 09. 2007.

The idea for this issue arose out of a seminar we organised, together with JeanFrançois Pérouse, in 2005-2006 at the Institut Français d'Etudes Anatoliennes (IFEA) in Istanbul on the 'Conditions of emergence of the Kurdish question within the Turkish academic field'1. We noticed that since the 1990s there had been a growing interest among Turkish scholarsi on the topic of Kurds and Kurdish questions. Until this very recent period, speaking about Kurds was a genuine taboo in Turkish universities; the experience of İsmail Beşikçi is representative of the imperviousness - and the harshness - of Turkish academia on this point. Then, it generally seemed that, in Turkey, academics only contributed to official ideology production by denying the existence of Kurds and Kurdish issues and that only non-academics dealt with it, surveyed it and spread information about it. Therefore the issue of knowledge appears to be very sensitive and tied to politics and ideologies. In this issue, we wanted to go back to the history of academic research on Kurds and to explore also contemporary studies. Why - and why now - has this issue attracted scholars' interest? In what sorts of conditions can they work and speak? Within which paradigms do they work and conduct research, with which objectives and for which applications?

[2] Our objective here is to propose a first 'state of art', with both epistemological and sociological perspectives. We will explore knowledge production about the Kurds - the conditions, stakes and actors involved in this knowledge production - and its transformation, if it occurs. Though we focus here on Turkey, our main field of research, we need to take into consideration the treatment of the question in Western countries as it influences, in diverse ways, the evolution of the Turkish field of research. We consider this present issue as a means of opening a debate and of offering a few first hypotheses and lines of research on this very wide question. Our issue includes articles dealing with production of knowledge about Kurds by different actors (the state, the Kurdish nationalists, the colonial powers) within different historical contexts. It also includes interviews with scholars who have worked on the question within different frameworks and contexts. We invited these scholars to consider the way they shaped their studies on Kurds, under which constraints and with which resources. They were also called upon to think about the possible transformations affecting in time and space what would be a field of Kurdish studies developing within and between different national frames. These

\footnotetext{
${ }^{1}$ We would like to thank Hamit Bozarslan and Nicole Watts for their helpful and stimulating comments.
} 
Scalbert-Yücel, Clémence and Ray, Marie Le (2006) 'Knowledge, ideology and power. Deconstructing Kurdish Studies', European Journal of Turkish Studies, Thematic Issue N ${ }^{\circ} 5$, Power, ideology, knowledge deconstructing Kurdish Studies, URL : http://www.ejts.org/document777.html To quote a passage, use paragraph (§).

interviews thus also contribute to give an evolving picture of the field both in European countries and in Turkey.

[3] Several questions are to be examined here. The first and the main one is to define the object within our scope. How should we talk about Kurds? This question leads to a second one: how should we talk about studies dealing with Kurds and Kurdish regions? What does 'Kurdish studies' and 'Kurdology' mean? How were they, historically, constructed as such? Is it possible - and with which scientific and political consequences to work on 'Kurds' without taking the issue of ethnicity into account? Indeed, the issue of ethnicity seems to be central since the object tends to be defined as an ethnic group; the works either stress or conceal the ethnicity and the conflict which can be considered, as least partly, to follow from it. What are the political and scientific stakes of such a categorisation? How do we avoid reification in such a polarised context? The question of the autonomy of a field of Kurdish studies is also central and related to the first questions. The autonomisation is two fold: autonomisation from both other fields of research - and here mainly Orientalist studies - and the wider social and political fields. Who are the main actors? Where and through which institutions is research produced?

[4] In order to start answering these questions, we will examine, in the first part, the development of a field of 'Kurdish studies' around the building of a specific - though evolving - object, around specific issues and specific institutions. We will see that a large part of these institutions are non academic and diasporic, located outside Kurdistan and Turkey. But this de-territorialized field is connected to Turkey through the circulation of humans, prints, and ideas. The second part of this paper is devoted to the diachronic presentation of the field of 'Kurdish Studies' in Turkey. Can we speak, in such a context of 'Kurdish Studies'? Has the field really emerged there? Have conditions of research and writing really changed?

\section{What is Kurdish Studies?}

\section{The object of Kurdish Studies}

[5] In order to give a first picture of the object of the 'Kurdish studies' we will present several generations of works done on 'Kurds' which appear to be representative of 
Scalbert-Yücel, Clémence and Ray, Marie Le (2006) 'Knowledge, ideology and power. Deconstructing Kurdish Studies', European Journal of Turkish Studies, Thematic Issue N ${ }^{\circ} 5$, Power, ideology, knowledge deconstructing Kurdish Studies, URL : http://www.ejts.org/document777.html To quote a passage, use paragraph (§).

the different steps of the building of the 'Kurdish studies' and of the paradigms within which they were undertaken. Those examples are mainly taken from the French academia we know better and which seems to have played an important role in the field. The first generation is represented by Basile Nikitine of the Orientalist tradition, the second by the left-wing researchers of the 1960 s to 1970 s who worked on the national question. Then we will present the first comparativist and more theoretical works on Kurdistan or the Kurdish question of the 1980-1990s, and the last generation, which seems to be more integrated in country studies.

'The spirit of the Kurdish people'

[6] Like many others Russian Orientalists, Basile Nikitine (1885-1960) served as Russian Consul. He was in post in Ourmiah (Iran) before and during the First World War. Like Alexandre Jaba, another 'founding father' of the Kurdish Studies, who served for a while in Erzurum as a Russian consul2, Nikitine, though a great scholar, had no orientalist formation and was not an academic. His book, Les Kurdes; Etude sociologique et historique, is the outcome of observations made in the region and of a wide range of readings. He wrote it in France where he became a refugee after the Soviet revolution. Though Basile Nikitine did not belong to the academy, his book was published with the support of the Centre National de la Recherche Scientifique (CNRS - National Centre of Scientific Research). It was prefaced by Louis Massignon (1883-1962) who held a dominant position in French Oriental Studies (islamologist, he held the chair of Muslim sociology in the Collège de France from 1926 to 1959). It is possible then to argue that the book was granted an important scientific legitimacy. It is the first monograph ever published on Kurds in France.

[7] The aim of the book is to describe the 'Kurd'. He writes: 'It is necessary to present him [the Kurdish people] as he is really, objectively, with his bad and good sides,

\footnotetext{
2 However, Leningrad University asked Jaba to collect and to work for the university as he was in post in the Kurdish areas. Contrary to those two diplomats, Minorsky who served for the Foreign Ministry received an orientalist formation and had a PhD (We would like to thank Joyce Blau for this information). Let's not forget that, in 1823, a section of oriental languages has been founded within the Russian Foreign Ministry. This section aimed at teaching practical notions useful for the service of diplomats. Lectures were often given by professors from the University. In 1890, it was given the function to teach officers too (Barthold 1947: 320321).
} 
Scalbert-Yücel, Clémence and Ray, Marie Le (2006) 'Knowledge, ideology and power. Deconstructing Kurdish Studies', European Journal of Turkish Studies, Thematic Issue N ${ }^{\circ} 5$, Power, ideology, knowledge deconstructing Kurdish Studies, URL : http://www.ejts.org/document777.html To quote a passage, use paragraph (§).

without adopting preconceived judgment' (Nikitine 1956: iv) ${ }^{3}$. The book describes different aspects of Kurds: their origins, history, ways of life, occupation, social organisation and culture. Chapter four is entitled 'Kurdish individuality, its character'. This chapter is relevant to understand how 'Kurds' were studied at the time. The author writes that each people has a 'national spirit' that consists of a 'set of features which distinguish or bring closer a people from an other' (Nikitine 1956: 65). Then the book presents those distinguishing features. The individuality and the unity of the Kurds are displayed. On the one hand, the chapter 1 dealing with the origins of the Kurds - displaying the most current theories (Oscar Marr; Vladimir Minorsky) - and on the other hand, the ideas of race and natural determinism that are developed strengthen this essentialist vision. Thomas Bois, writing not only in the 1940s but even in the 1960s, described the 'Kurds' spirit' (Bois 1946, 1963a). Then, the object of Kurdology - Nikitine uses the words of 'Kurdology' and 'kurdisants'(Nikitine 1932, 1956) - embraces all aspects of life, culture and history of the Kurds, a well distinguished people, within very different disciplines (ethnology, archaeology, history, linguistics, etc.).

[8] This kind of monograph, characteristic of the savant tradition at that time, helps develop an essentialist presentation of a people. It is, however, only great scholars, combining a knowledge of the field and a huge amount of readings, who are able to put together such comprehensive monographs. Certainly also because the ways of conducting research have changed, after Nikitine, in France, no one undertook such a work.

[9] It is, however, interesting to mention here the book of the American academic of Kurdish origin, Mehrad Izady (1992), whose form is very similar to the Nikitine's. It presents an even more essentialist vision, but differs certainly in its aims from Nikitine's book: his heavy nationalist view is quite openly displayed ${ }^{4}$. This book has been distributed on a large scale, even in Turkey where it has been published recently (2004).

[10] Works produced in Western countries at the time of Nikitine nourished the process of Kurdish national identity construction; it served and legitimated political demands of the Kurds within the formulation of a 'Kurdish Question'. Jordi Tejel studies the connection between French 'kurdologues' (Roger Lescot and Pierre Rondot) and Kurdish nationalists in Syria and Lebanon under the French Mandate. He shows that the works of

\footnotetext{
3 We have translated all foreign languages works quoted in this article.

${ }^{4}$ For a very good critique of Izady's book, see O'Shea (2004).
} 
Scalbert-Yücel, Clémence and Ray, Marie Le (2006) 'Knowledge, ideology and power. Deconstructing Kurdish Studies', European Journal of Turkish Studies, Thematic Issue N ${ }^{\circ} 5$, Power, ideology, knowledge deconstructing Kurdish Studies, URL : http://www.ejts.org/document777.html To quote a passage, use paragraph (§).

these 'kurdologues' played a crucial role in ethnicising and delimiting a specific Kurdish identity that was then appropriated and spread by the Kurdish nationalist elites (Tejel 2006).

\section{Putting the 'Kurdish question' in words}

[11] A second generation of academic works appeared from the 1960s onwards in France and dealt with the Kurdish question formulated as a political question. The renewal of interest in Kurds is clearly linked to the political events bringing the Kurds back to the forefront of the international political scene: the revolt of Mustafa Barzani in Iraq in 1961 and 1975; guerrilla warfare in Iran and Turkey from the 1970s to the 1990s; the Iran-Iraq war and the different Gulf wars; and, last but not least, the growing presence in Europe of a Kurdish diaspora which brought the Kurds, quite literally, closer. Academic approaches to the question were also connected to those political events. It is indeed through the frames of the national struggle, people and minority rights that the question was studied. Concepts used by researchers seemed to be very dependent on the political context of the Kurdish region within which the research was undertaken. Moreover, the presence in the West of representatives of the Kurdish national movement also played a role in the discovering of the issue and in the way it has been worded.

[12] The 'Kurdish question' was first explicitly formulated by the Kurds living outside Kurdistan, in Europe. The first mention of the 'Kurdish question' was made in a book signed by Dr. Bletch Chirguh (the pseudonym of Celadet Bedirkhan) published by the national organisation Khoybûn in $1930^{5}$. This book aims at presenting the Kurdish nation to the 'civilised world' (Chirguh 1930: 3). The Kurdish question is constituted by 'the struggles that have lasted for more than three centuries and that have always aimed at national independence' (Chirguh 1930: 13). The Kurdish question is mainly considered by the Bedirkhan brothers in the context of Kurdish-Turkish antagonism which, according to Bedirkhan, goes back to 1847 (the date of the abolition of the last Kurdish emirate). Indeed, the Bedirkhan, at the head of the Khoybûn organisation, were coming from Turkey and the organisation was mainly concerned with Turkey's Kurds and Kurdistan. Thirty years after the publication of Chirguh's book, Kamuran Bedirkhan, in another book in French, La question kurde, defined the question in similar terms: 'it is the fight of the

\footnotetext{
${ }^{5}$ On Khoybûn, see Tejel (2007) and Tejel 2006.
} 
Scalbert-Yücel, Clémence and Ray, Marie Le (2006) 'Knowledge, ideology and power. Deconstructing Kurdish Studies', European Journal of Turkish Studies, Thematic Issue N ${ }^{\circ} 5$, Power, ideology, knowledge deconstructing Kurdish Studies, URL : http://www.ejts.org/document777.html To quote a passage, use paragraph (§).

Kurdish people since one century for its liberation. It is the natural and instinctive impetus of this people who wants to remain Kurd, to speak freely his language and preserve his national patrimony [...] The Kurdish question consists in convincing the states that share Kurdistan to behave towards the Kurds in accordance with the juridical and moral principles universally acknowledged and inscribed in the United Nations Charter and in the Declaration of Human Rights' (Bedirkhan 1958: 1). The booklet also provides details about the different steps that built the issue: the main one is the so called 'second partition' of Kurdistan at the end of the First World War, with the support of the Western powers (Bedirkhan 1958: 8-9). This period, with the Treaties of Sevres and Lausanne, then takes a fundamental place in Kurdish as well as in Turkish historiography: it symbolised the possibility of a Kurdish state and the threat of the division of the Turkish one.

[13] In 1970, Ismet Cherif Vanly published his PhD thesis on Iraqi Kurdistan and the national question. Like Bedirkhan did before him in the 1930s, he defined the Kurdish question as a 'question of national liberation'b. Although he sometimes uses a Marxist conceptual frame, he also considers the nation as timeless and natural. We can read in Bedirkhan and Vanly that the nation, 'fruit of the nature' (Vanly 1970: 31), is fighting for many centuries. The national feeling is said to go back to the $16^{\text {th }}$ century (Vanly 1970: 31). Such an historical background legitimizes both the fight against oppression and for national liberation. Of course, scientific works essentializing the nation and its 'spirit' play a role here by feeding the idea of a timeless nation and of ancestral fights against the oppressor. Timelessness legitimizes the present fights and demands. The analyses of the issue are based on the perception of a timeless nation and of an unchanging relationship between the (oppressive) states and the (oppressed) Kurds. But, here, we remain within the strictly political writings. They are, however, important to understand how the question will be formulated by Western - at least French - academics.

[14] Bedirkhan's booklet, written at the time of the Iraqi Revolution of General Kassem (1958), backs both the Iraqi General and Mustafa Barzani. At that time, effectively, Kamuran Bedirkhan was representing Barzani's movement in Europe. Like Bedirkhan, Vanly was also a PDK (Democratic Party of Kurdistan) representative in Europe. Both went through the academy. Kamuran even held the chair of Kurdish language at the Ecole Nationale des Langues Orientales Vivantes in Paris (which became later the Institut 
Scalbert-Yücel, Clémence and Ray, Marie Le (2006) 'Knowledge, ideology and power. Deconstructing Kurdish Studies', European Journal of Turkish Studies, Thematic Issue N ${ }^{\circ} 5$, Power, ideology, knowledge deconstructing Kurdish Studies, URL : http://www.ejts.org/document777.html To quote a passage, use paragraph (§).

National des Langues et Civilisations Orientales, INALCO) between 1948 and 1970. At that time there were still few Kurdish students in Europe, and many of those who were there were connected to politics. Kamuran Bedirkhan was the main Kurdish political and academic figure in Europe and played an important role in gathering these students together. It was mainly through this circle that Europe - at least France - became aware of the Kurdish issue, and it was their definition of the Kurdish issue that was best known. Hence the question was studied as a question of 'national liberation' - then in vogue with the movements of decolonisation. For example, Joyce Blau became aware of the Kurdish question through her political commitment and her encounter with Kamuran Bedirkhan (Blau 2006). The experience of Martin Van Bruinessen also confirms the importance of the researcher's political commitment (Van Bruinessen 2006). After that, Joyce Blau wrote a thesis on Kurdish national question and on the Kurdish problem. Jean-Pierre Viennot, who taught for a while at the INALCO also wrote a PhD at the Sorbonne University in 1969. The first French writers interested in Kurds were Chris Kutschera and Gérard Chaliand. The main contributions of Chaliand's book (Les Kurdes et le Kurdistan. La question nationale kurde au Proche Orient) were written by representatives of the Kurdish movement among them some were also belonging to the academia - (A. R. Ghassemlou and İsmet Cherif Vanly). The profits of the book have been donated to a Kurdish organisation. Chaliand defines these writers as 'Kurdish intellectuals critically exploring the legacy of the national movement' (1979: 29). The preface, written by Maxime Rodinson - who is, like Massignon, a dominant figure in the French field of Oriental Studies but with very different political views and influent on Marxist Arab intelligentsia - is very explicit: it is a book 'that puts forward and illustrates the Kurdish question, that defends the national demands of Kurds' (1979: 7). It was written for the leftist public opinion ignorant of an issue the author considered as the most important remaining after the settlement of the colonial questionii (1979: 17). This book, written by committed Kurdish and European writers really aims to back the movement. All the writers working on the issue in France at the time were in the same vein; books were written through first hand experiences, secondary sources or archival documents (especially Kutschera 1979 made a great use of European archives).

[15] It seems that Kurdish nationalists who were studying, teaching or working in Europe played a major role in spreading information about the Kurds and in shaping the Kurdish question in the direction of a mainly European (more or less) academic audience. However, these Kurdish writers (notably the Bedirkhan) were not of Marxist trend and the 
Scalbert-Yücel, Clémence and Ray, Marie Le (2006) 'Knowledge, ideology and power. Deconstructing Kurdish Studies', European Journal of Turkish Studies, Thematic Issue N ${ }^{\circ} 5$, Power, ideology, knowledge deconstructing Kurdish Studies, URL : http://www.ejts.org/document777.html To quote a passage, use paragraph (§).

Kurdish struggle was not perceived within the scope of Marxism. The meeting between these nationalists and the French researchers was then determinant. Indeed, the first French researchers (whether academics, like Blau or Chaliand, or reporters, like Kutschera) who started to study the issue were politically active in the left or influenced by Marxism, anti-colonialism and theories of liberation struggle. The Kurds were considered as a specific cause among others and perceived through the same categories as colonised or Vietnamese peoples.

[16] It is, moreover, important to remember that, at the very time Kamuran Bedirkhan wrote his booklet on the 'Kurdish question', formulated as a national question, there were in Turkey neither Kurdish national claims nor Kurdish political parties ${ }^{7}$. The main problem to be raised, as shown in a book well representative of the period, Doğu'nun Sorunları (Bozarslan 1966), was mainly worded as the 'Eastern Question', rather a question of economic and social (under) development more than a national one. This enables us to perceive the gap between Western and Turkish perceptions of the issue and categories used. The spreading of Marxism later on in Turkey will modify the political formulation of the Kurdish question.

[17] Usually, all the books dealing with the issue studied it in a fragmented way. They have similar structures: they deal either with the Kurdish issue in a specific country (as Hoybûn in Turkey, Vanly in Iraq) or with the whole issue but each chapter is devoted to the issue in each of the countries concerned. The last works are most often collective books - as Chaliand (1979) or, later, Picard (1993). The introductory chapter deals with the Kurds in the Ottoman Empire, and ends with the treaties of Sevres and Lausanne. Each of the following chapters deals with the Kurdish issue in Turkey, in Iran, in Iraq or in Syria with no real comparative means. Picard's book, however, presents three final chapters on Kurdish nationalism and minorities issues that introduce a first comparative dimension. Moreover, the main object of those studies is not to understand the Kurds themselves but rather to understand the relationships between the Kurds (either considered as minorities or as national movements) and the states. The titles of these works and the following ones in the 1990s, still focusing on the 'issue', underline this approach: the special issue of the journal Peuples Méditerranéens published in 1994 is entitled 'Kurds and the states', the subheading of Bozarslan's La question kurde is 'states and minorities'.

\footnotetext{
${ }^{7}$ The KDP-T was founded in the late 1960s.
} 
Scalbert-Yücel, Clémence and Ray, Marie Le (2006) 'Knowledge, ideology and power. Deconstructing Kurdish Studies', European Journal of Turkish Studies, Thematic Issue N ${ }^{\circ} 5$, Power, ideology, knowledge deconstructing Kurdish Studies, URL : http://www.ejts.org/document777.html To quote a passage, use paragraph (§).

Towards comparative works

[18] Comparison is, however, introduced through space and time. The most important comparative work dealing with the Kurdish question and introducing a new and more theoretical approach is by Bozarslan: La question kurde Etats et minorités au MoyenOrient. The introduction, in the analysis, of comparatism and scale shifting is innovatory. The work gives comprehensive analyses of both the strategies of the relevant states towards their Kurdish minorities and the strategies of the different nationalist movements. Then it provides suggestions about the state-minority or centre-periphery relationships in the Kurdish case that could also serve as a model for research on other minority-state relationships, especially in the Middle East. The author acknowledges the existence of separate Kurdish questions within each state which he puts into comparison - his work exposes the division of the movements and of the Kurds within different countries, divisions which were, though not explicitly discussed, perceptible in the shape of the previous works (Bozarslan 1997: 312) iii. However he underlines the regional and cross-border dimension of the question, and the conceptualisation of a 'cross-border conflictuality' and a 'parallel diplomacy': the Kurds are not simply a minority confronting the state but regional and even international actors engaged in negotiations with different neighbour states (Bozarslan 2006).

[19] The work also presents the first complete analysis of the emergence and development of a Kurdish nationalist discourse - or a panKurdist discourse - often in contradiction to the fragmentation of the Kurdish movement and question and with the different levels of identification, whether tribal or ethnic (Bozarslan 1997, chapters 2 and 5). It contributes to change our vision of the Kurds - as presented by the first generation of works - as a timeless people. In the 1990s, studies on Kurdish nationalism and Kurdish national identity's building process developed and encouraged this direction of inquiry. Indeed, as nation and identity are then perceived as a construct, the diachronic dimension is taken into account and leads necessarily to the deconstruction of what was considered an immutable object with precise and unquestionable boundaries. Gilles Dorronsoro comes back to an important historiographical debate that argues that the village guards (korucu) are the extension of the Hamidiye regiment. The in-depth comparison he undertakes enables us to critique the idea that the Republican policies towards Kurds were the extension of the imperial ones. Thus, historical comparison and diachronic perspectives 
Scalbert-Yücel, Clémence and Ray, Marie Le (2006) 'Knowledge, ideology and power. Deconstructing Kurdish Studies', European Journal of Turkish Studies, Thematic Issue N5, Power, ideology, knowledge deconstructing Kurdish Studies, URL : http://www.ejts.org/document777.html To quote a passage, use paragraph (§).

enables us to de-reify both the object - the Kurds - and their relationship to the states (Dorronsoro 2006).

[20] For sure, Martin Van Bruinessen's works (1992a, 1994) carry such ideas, deconstructing the idea of the unity of the Kurdish people and the image of a 'typical' Kurd, while revealing diverse and intertwined identities. It enables a de-reified analytical process. Van Bruinessen's work on primordial loyalties in Kurdistan has certainly been one of the factors which led the author to these remarks: indeed in the concluding remarks of his work, he stated: 'such loyalties come more naturally to people than those towards wider and more abstract entities such as nation or class and more easily fulfil the need to belong to an identifiable group' (Van Bruinessen 1992a: 317).

[21] In an other disciplinary field, anthropology, Martin Van Bruinessen also opened a way for comparison with his $\mathrm{PhD}$ thesis Agha, Shaikh and the State; The Social and Political Structures of Kurdistan originally written in 1978 and published first in 1989 in German and then in 1991 in Turkish and in 1992 in English. The aim of the work was to study the 'primordial loyalties'8 in Kurdistan in interdependence with external factors (notably the state) that influenced and modified loyalty systems. To complete this project, the author undertook extensive fieldwork that, he thought, would allow him to 'collect hard data rather than the vague impressions that abound in the literature on Kurds' (Van Bruinessen 1992a: 4). The researcher departs from traditional works about Kurds that are based on observations and readings. He is the first European researcher to undertake such anthropological fieldwork and to collect first hand data in Kurdistan ${ }^{9}$. He did his fieldwork in four countries (Iran, Iraq, Turkey and Syria) more by necessity than by choice (Van Bruinessen 1992a: 3-6). However, due to political constraints, he stayed short times in different places, and he says that it was then impossible to collect quantitative data. The unstructured interviews he conducted enabled him to collect good data but they were difficult to compare (1992a: 5). Nonetheless, his inability to stay in Iran, the only country in which he had originally planned to do field work, did encourage him to collect data on social organisation in the whole of Kurdistan. Because of this, even if he focuses more on

8 He uses Alavi's definition of primordial loyalties: 'Group ties such as kinship and caste that prevent poor peasants perceiving class contradictions and that make them act against their objective interests' (Alavi 1973 in Van Bruinessen 1992a: 5).

${ }^{9}$ First fieldwork was done, however, by linguists (like Joyce Blau or David N. Mackenzie) who needed less time to collect their materials. Their position in the field was also easier as the work was not considered as 'political' (Blau 2006). It is important also to mention the precursor work of the anthropologist Frederik Barth (1953). 
Scalbert-Yücel, Clémence and Ray, Marie Le (2006) 'Knowledge, ideology and power. Deconstructing Kurdish Studies', European Journal of Turkish Studies, Thematic Issue N ${ }^{\circ} 5$, Power, ideology, knowledge deconstructing Kurdish Studies, URL : http://www.ejts.org/document777.html To quote a passage, use paragraph (§).

the relationship between the state and Kurdish tribes or religious figures in the Ottoman Empire and Republican Turkey, he offers a broader vision of the system of loyalty in Kurdistan (Van Bruinessen 2006). By introducing theoretical concerns, approached through comparative methods, these works distinguish themselves from the Orientalist tradition represented here by Nikitine (Bozarslan 2000).

Kurds within the fields of countries and disciplines' studies: constraints due to the context and the dispersion of Kurds.

[22] Fieldwork is today more and more carried out in social sciences. It is generally done in a small circumscribed area that is usually situated within the territory of a state. The fact that the Kurdish population is scattered within at least four states makes work harder. Comparative fieldwork is very difficult to undertake as it demands the researcher master different languages, as well as be acquainted with different histories and social and political cultures. It is a fact today - and nearly a necessity owing to research conditions that Kurds are studied in one or another specific country and, most often, in interrelation with this state. Comparison would be very interesting; however, it is very rarely undertaken. Moreover these studies - maybe precisely because they are geographically circumscribed do not aim at studying the Kurds per se but a specific political system, forms of mobilisations, the production of identities, in other words, 'micro-objects' which are not defined first by ethnicity but which can include it. All these 'micro-objects' are analysed in a peculiar context that is more often a national context. It is then considered as a case to understand a phenomenon at the national scale. Kurds are then only a part of the object of the research. Jean-François Pérouse's assumption, enhancing constructivism, also led us to accept the reality of the contemporary research conditions and to think again about our object: 'Our object is not to 'produce' a history of Turkey's Kurds, separated from the general, contemporary Turkish history, which would amount to a sharp cut into the interactions and intermingling, and to a too partial approach, but rather to place the Kurds into a history they fully, and in an inextricable way, participate in. This is to be done by avoiding two hazards: on the one hand, denial, or the assimilator paradigm (depriving the Kurds of proper characteristics) and, on the other hand, segmentation, which would introduce complex social, political, economic and territorial cuts' (Pérouse 2005: 358). This approach leads not to fragment a priori the populations and the issues. Such works, like 
Scalbert-Yücel, Clémence and Ray, Marie Le (2006) 'Knowledge, ideology and power. Deconstructing Kurdish Studies', European Journal of Turkish Studies, Thematic Issue N ${ }^{\circ} 5$, Power, ideology, knowledge deconstructing Kurdish Studies, URL : http://www.ejts.org/document777.html To quote a passage, use paragraph (§).

Bozarslan's History of contemporary Turkey (2004), square with the assertion of Pérouse. Integrating many different national, ethnic or religious issues (such as the Alevi, the Armenian or the Kurdish ones) to a general history of Turkey is quite a feat. If it could change the conception of studying the Kurdish issue it may also change the way people are working in the field of Turkish studies. These ways of working certainly make the object 'Kurds' more complex and lead necessarily to more complex theoretical analysis, going beyond the only - impossible - stake to define what the Kurds are.

\section{The institutions of Kurdology: the building of a deterritorialized field}

[23] If the object 'Kurds' of the 'Kurdish studies' is being deconstructed by more scientific research, 'Kurdish studies' or Kurdology has been built through time as a specific field of research and exists today as a scholarly (savant) institution. It exists mainly outside the countries directly affected by significant Kurdish populations because it has not been possible to carry out explicit research on Kurds in Turkey, Iran, Iraq or Syria. This is certainly also why Kurdology gained political connotations. On the one hand, the role of Russia and USSR in the establishment of a specific discipline called Kurdology is essential. It is certainly to understand within the scope of the soviet nationality policies. On the other hand, the role of the Kurdist movement ${ }^{10}$ in the diffusion of the term is dominant.

The role of Russian and Soviet research

[24] For all researchers, Russia is the place where Kurdology was born by differentiating itself from Iranology (itself within the field of Oriental studies). It was in the $19^{\text {th }}$ century that studies of Kurdish society and language developed. It corresponds to the time the Russian army regularly waged war against the Persian and Ottoman Empires. Kurds were discovered at this time as they were located on the margins of these Empires, adjacent to the Russian one. Scientific interest in the Kurds increased strongly after the Crimean war. From then on, studies on Kurdish culture and language developed in the Empire's universities, mainly in the Imperial Academy of Sciences in Saint Petersburg

10 We prefer to talk here about 'Kurdist' movement(s) rather than about a Kurdish national movement. The term of 'Kurdist movement' refers here to a wide range of individual or institutions all mobilised around the issue of Kurdish identity but bearing different objectives (going from the acknowledgement of this identity to the national independence). 
Scalbert-Yücel, Clémence and Ray, Marie Le (2006) 'Knowledge, ideology and power. Deconstructing Kurdish Studies', European Journal of Turkish Studies, Thematic Issue N ${ }^{\circ} 5$, Power, ideology, knowledge deconstructing Kurdish Studies, URL : http://www.ejts.org/document777.html To quote a passage, use paragraph (§).

(later to become Leningrad) ${ }^{11}$. Soviet Kurdology extended the Russian Kurdology under the direction of A. A. Frejman and I. A. Orbeli. The former founded a seminar on Kurdish linguistics within the faculty of Language of Leningrad University (1931). Orbeli - who developed the first Kurdish Roman alphabet -taught Kurdish in Petersburg (and Leningrad) from 1915 to 1934 and, in 1959, founded a Kurdish section (Kurdskij Kabinet) within the Institute of Asian People of USSR's Sciences Academy in Leningrad. Linguist and historian Qanatê Kurdo ${ }^{12}$, who first taught Kurdish language at the Faculty of Philology and at the Iranology department of the Orientalism faculty in Leningrad, succeeded Orbeli at the direction of the Kurdskij Kabinet in 1961. Both played an important role in this domain as they trained many students. Leningrad remained the centre of Kurdish Studies and a lot of students who specialised in Kurdish studies went there. Kurdish Studies was also present in this city at the Institute of Ethnography and the Institute of Orientalism. In Moscow research on Kurds was found in the Institutes of Philology, of Ethnology and of Orientalism ${ }^{13}$ of the USSR Academy of Science.

[25] However, the institutionalisation of Kurdology as a discipline (with a specific section and lectures) seems to have taken place first in Soviet Armenia. Indeed the first panSoviet Congress of Kurdology was held in July 1934 in Yerevan on the initiative of the Armenian Communist Party's Central Comity. With the decision to publish dictionaries and grammars, it boosted Kurdish linguistic works in the country ${ }^{14}$. One of the decisions of this Congress was to develop Kurdology in the main Soviet cities of Moscow and Leningrad. A section of Orientalism was opened in 1934 in the Academy of Science of Armenia and students were sent to Leningrad in order to get trained. Four working groups were founded: Turcology, Arabistic Studies, Iranology and Kurdology. Yerevan was then the second big Soviet centre in the field of Kurdology after Leningrad. Today, research on Kurdish languages, literature, ethnology and history are undertaken within the Caucasian Centre

11 They are marked by the works of Alexandre Jaba (1801-1894), P.I. Lerx (1827-1884), A Chodzko, or by F. B. Charmoy (1793-1869) who translated the Cherefname. Moreover tsarist Russia also drew foreign researchers who worked or published in Petersburg.

12 Qanatê Kurdo originated from Kars. He and his family flew to Armenia in 1918. In 1928, the Central Committee of the Armenian Communist Party sent him with seven other Kurds to study in Leningrad. There he was taught by Orbeli or Frejman (Blau 1986).

13 The Institute of Orientalism of the Academy of Science is known as the Institute for the Studies of Asian peoples (Institut Narodov Azii). The Faculty of Ethnology was founded in 1920 and shut down in 1931. The Institute of Ethnology was founded in 1934 with the aim of studying peoples' ways of life, material culture, traditions, and cultural survival. About this Institute, see Goujon (2006).

14 The Congress also made compulsory the use of the Kurdish Latin alphabet in the USSR. It was used until 1938, when Staline advocated a shift toward the Cyrillic script (Blau 1996). 
Scalbert-Yücel, Clémence and Ray, Marie Le (2006) 'Knowledge, ideology and power. Deconstructing Kurdish Studies', European Journal of Turkish Studies, Thematic Issue N5, Power, ideology, knowledge deconstructing Kurdish Studies, URL : http://www.ejts.org/document777.html To quote a passage, use paragraph (\$).

for Iranian Studies and in the Department of Iranian Studies in the Yerevan state University. There is a Masters course on Kurdology in the Department of Iranian Studies.

[26] The four important Kurdology centres in the USSR were located in Leningrad, Yerevan, Moscou and Bakou (a section of Kurdology has existed there since 1959). Kurdology is named as such. For Alakom (1991: 9-10), the term of 'Kurdish Studies' first appeared in 1840 (Rödiger; Pott 1840) and the one of Kurdology is more and more used since the Yerevan Congress of 1934. Named as such, it is considered as an independent field of research, independent from Iranology within which it started. Within these Kurdology sections, Kurdish language and linguistics, literature, folklore, ethnology and history are the main fields of investigation. The object of Kurdology is the Kurds within the scope of different disciplines and in the whole of the Kurdish populated area, Kurdistan ${ }^{15}$. This discipline emerged as an independent one with its own institutions such as congresses, Kurdish chairs and Kurdish cabinet in the USSR. The use of the term developed there and Kurdology grew up as an academic domain.

[27] Such a similar centre also appeared in France within the Ecole Nationale des Langues Orientales Vivantes in Paris (later to become the Institut National des Langues et Civilisations Orientales (NALCO). A course on Kurdish language was begun in 1945, lectured first by Roger Lescot. The chair was really founded in 1960 for Kamuran Bedirkhan who had been there since 1948. In 1966, a course on Kurdish civilisation was introduced, lectured by Thomas Bois. Slowly, more courses were begun: Kurdish language (both Kurmanci and Sorani since the early 1970s), Kurdish literature, civilisation (or culture), history, media, and geography. Masters and PhDs are offered within the section of Kurdish language and civilisation founded in the $1970 \mathrm{~s}^{16}$. The opening of a separate section obviously holds political stakes. It acknowledges indeed the specificity of the Kurdish people, suggesting that he deserves specific study. Here also, Kurds remain as an object of study, well distinguished from the Turks or Persians, studied in the frame of Turkish or Persian languages and civilisations. The organisation of the courses as well as the very word civilisation emphasize the essential character of the Kurds and their own cultural and social characteristics - well distinguished from the ones of the other peoples and which the courses aim at defining and studying as a peculiar object.

${ }^{15}$ For a presentation in European languages of the Kurdish studies in Russia and USSR, see Mokri (1963) and Benningsen (1960).

16 Kurdish Language and Civilisation's section is part of the Eurasia Department. For a history of these courses and a presentation of the teaching staff see Blau (1995). 
Scalbert-Yücel, Clémence and Ray, Marie Le (2006) 'Knowledge, ideology and power. Deconstructing Kurdish Studies', European Journal of Turkish Studies, Thematic Issue N ${ }^{\circ} 5$, Power, ideology, knowledge deconstructing Kurdish Studies, URL : http://www.ejts.org/document777.html To quote a passage, use paragraph (§).

[28] Other centres of Kurdish Studies have been or are being founded in European universities such as the Department of Iranology of the University of Göttingen and the Institute of Arab and Islamic Studies of the University of Exeter.

\section{The role of Kurdish centres in Europe}

[29] A number of non-academic independent Kurdish Institutes or Research Centres in Europe also played a significant role in the development and promotion of Kurdish Studies defined as such. Those institutions all deplore the fact that Kurdology, a rich field with great potential, is still under-developed. For those institutions, that is mainly due to the political situation. The ruling states are said to have done all they could to limit and prevent research on these topics ${ }^{17}$. These institutions generally aim to remedy to this tendency. Indeed, much more than the universities (even the Western ones), they have promoted research on Kurds. The Kurdish Institute in Paris (KIP) was opened in Paris in 1983 under the direction of Kurdish intellectuals and artists and Western specialists of Kurds. First created as an association, it became a foundation in 1993. The aims of the Institute are to preserve Kurdish language, history and patrimony, to contribute to the integration of Kurdish migrants in Europe and to make known the Kurdish people, history and the contemporary situation to European audiences. The Institute is managed by a board of directors including a large number of academics (Abbas Vali, Fuad Hussein, Joyce Blau) under the direction of Kendal Nezan. The Institute has also founded a scientific and cultural board including five sections, dealing respectively with social sciences, language and literature, arts, human rights and information and socio-cultural activities. It is very active in the field of research through the attribution of fellowships, the organisation of conferences and colloquiums, and the publication of scientific journals: Studia Kurdica (1984-1993) and Etudes Kurdes (since 2000). Etudes Kurdes is directed by Joyce Blau, Hamit Bozarslan and Salih Akin. With the exception of Kendal Nezan, director of the Institute, all members of the scientific and editorial boards are academics working in the West. It is the same for the Journal of Kurdish Studies (published in the USA since 1995). Though not directly related to the Paris Kurdish Institute, it is very close to it, as 
Scalbert-Yücel, Clémence and Ray, Marie Le (2006) 'Knowledge, ideology and power. Deconstructing Kurdish Studies', European Journal of Turkish Studies, Thematic Issue N ${ }^{\circ} 5$, Power, ideology, knowledge deconstructing Kurdish Studies, URL : http://www.ejts.org/document777.html To quote a passage, use paragraph (§).

demonstrated by its editorial board ${ }^{18}$. In their editorials, these two journals assert that Kurdish Studies is flourishing. The aim of these journals is to publicize this research to a wide audience, and mostly to an audience of specialists, but also to become an international forum for researchers on Kurds and Kurdistan. The aims of Etudes kurdes, through the publication of a chronology, book reviews, documents, archives, is to become a tool for scholars studying the Kurds.

[30] Another journal to mention as an actor of this field is the International Journal of Kurdish Studies. It has been published since 1986 under the auspices of the Kurdish Heritage Foundation of America (founded in 1981 as a 'Kurdish Program in the United States of America') which is mainly known to have founded a Kurdish library (1986) and Museum (1988) in New York. The journal aims at publishing researches, analysis, and commentaries on Kurdish history, culture, and contemporary affairs ${ }^{19}$. The Washington Kurdish Institute (WKI) is another institution conducting academic activities in the USA. It is a non-profit, research and educational organization, established in 1996, working 'for Kurdish People worldwide'. WKI amplifies informed, independent perspectives of issues that affect Kurds and bear directly on regional stability and U.S. national interests. Among its advisory committee are found academics working on the Kurdish issue world-wide (like Michael Chyet, Martin Van Bruinessen, Joyce Blau, Amir Hassanpour, Abbas Vali, etc.). Among many different projects, it has also worked as a research institution with, for example, the attribution of a research fellowship.

[31] The Berliner Society for the progress of Kurdology (Berliner Gesellschaft zur Förderung der Kurdologie - BGFK) is a private research institution that aims to promote interdisciplinary scientific research about Kurds in the diaspora and in their countries of origin. It is run by young researchers, the majority of whom studied in Berlin Freier Universität within which they launched the work of the Society. It was officially founded in 1999 but as early as 1993 it had organised a wide range of conferences, congresses and workshops. It has two main publications: the journals Kurdologie (since 1997) and Kurdische Studien (since 2001).

18 The editors of the Journal of Kurdish Studies are Joyce Blau (France) and Keith Hitchins (USA) and the editorial board is composed by Peter Kreyenbroek, Gilberd Lazard, Pierre Lecoq, Mackenzie, Kendal Nezan and Martin Van Bruinessen.

19 However, it may represent a particular tendency of the academic research on Kurds, more sensitive than the other journals to nationalist feelings (with regular papers of Mehrad Izady, for example). 
Scalbert-Yücel, Clémence and Ray, Marie Le (2006) 'Knowledge, ideology and power. Deconstructing Kurdish Studies', European Journal of Turkish Studies, Thematic Issue N ${ }^{\circ} 5$, Power, ideology, knowledge deconstructing Kurdish Studies, URL : http://www.ejts.org/document777.html To quote a passage, use paragraph (§).

[32] Most of these institutions are not academic institutions properly speaking since their aims go well beyond scientific research. They are, however, the only institutions that publish academic journals, organize scientific meetings and provide fellowships for researchers working more or less directly on Kurdish issues. Nothing like this has been done yet by the universities mentioned above though they own chairs of Kurdish language or even Kurdish Studies sections. Those organisations and centres, by constantly referring to 'Kurdology' and 'Kurdish Studies' (as seen for example in the titles of the journals or in the name of colloquiums), are the main actors contributing to the formation of a field of Kurdish Studies or Kurdology whose aim is to foster and to spread a multidisciplinary research about the Kurds. They gather all researchers working on Kurds in the world whether concretely (at meetings) or symbolically (within journals or by establishing researcher directories). They have also established close ties with the universities mentioned above. Moreover, all the above-mentioned institutions are related one to another, working together: for example, Kendal Nezan, president of the KIP is also a member of the board of directors of the WKI and of the editorial board of the Journal of Kurdish Studies. Among them, the Kurdish Institute in Paris is certainly at the centre of a broader network and the dominant actor of the field: it is the first institution of this kind founded and the most active in the field of research. Meetings organised in Paris, on different subjects, regularly gather many researchers. A diasporic research network emerged that links together academic and non-academic researchers (journalists, independent and autodidact researchers, etc.) as well as humanitarian workers. Thus, we can already assert that such a field of Kurdish Studies is well constituted, and that it mixes academic and non-academic scholars and sectors. The non-academic sector is leading because the scholars are scattered, and because the universities cannot gather enough students and enough money to undertake such high levels of activities as those organised by a single institution.

[33] With Iraqi Kurdistan developing a quasi-state status and its own academic institutions, ties between these diasporic institutions and the universities of Iraqi Kurdistan are being built. All of the mentioned Institutes and Foundations have approved agreements with these universities. WKI, in close relation with the Kurdish Regional Government, has established programs in collaboration with three universities of Iraqi Kurdistan in order to make easier international exchange. BGFK, in August 2002, has met with the Presidents of 
Scalbert-Yücel, Clémence and Ray, Marie Le (2006) 'Knowledge, ideology and power. Deconstructing Kurdish Studies', European Journal of Turkish Studies, Thematic Issue N ${ }^{\circ} 5$, Power, ideology, knowledge deconstructing Kurdish Studies, URL : http://www.ejts.org/document777.html To quote a passage, use paragraph (§).

the Universities of Dohuk, Suleimaniye and Erbil20. An agreement has been signed according to which work will be coordinated, and books and publications will be exchanged. Most recently, the KIP showed its capacity to work together with Iraqi Institutions through the organisation of the First World Congress of Kurdish Studies held in Erbil in September 2006. This colloquium was organised in partnership with Salahadin University in Erbil. In his introductory speech, Kendal Nezan described the event as follows: 'this event is both important and highly symbolic. Important because, for the first time, the majority of those research workers and academics throughout the world who have devoted their work to knowledge of the Kurdish people, its history, its culture, its language and its social and political situation, are all meeting here together. And this highly symbolic event is taking place in Erbil, in the capital of a Kurdistan'. The objectives of such an event are 'to make an inventory of the various areas of Kurdish Studies' and 'to discuss the perspectives and draw up concrete proposals for the future'21. The colloquium thus aimed to be a first step in the development and in the reunion of a Kurdish Studies field and to form a platform of discussion, exchange and cooperation among researchers interested in Kurds. The colloquium indeed presented, country by country, the works made on Kurds by academics and non academic researchers or journalists and took stock of the situation in those countries. No disciplinary or thematic workshop was organised.

[34] What about Turkey? Turkish actors are absent of the field. Apart the owner of Avesta publishing house, no one from a Turkish university or Turkey's Kurdish cultural centres was present and talked in Erbil for example. It may be difficult for Turkish academics to go to Iraqi Kurdistan to participate in a conference organised by the KIP. However, what about the members of the few Kurdish institutes founded in the 1990s in Turkey intending research as their main objective? The most important one is the Istanbul Kurdish Institute (IKI) founded in 1992. Like the Kurdish institutes and centres in Europe, it works on Kurdish language (it published two big Kurdish-Turkish and Turkish-Kurdish dictionaries) and on Kurdish history or folklore (with quite an important amount of publications). However, it clearly stands outside the field and never works in collaboration with the other actors mentioned above. For example, people working in Istanbul on Kurdish language never participated in the 'Kurmancî' meetings organised twice a year by the KIP to collect Kurmanci's vocabulary. We can suggest a few hypotheses to explain this split

20 Note that Dohuk University has opened a 'Kurdish Studies Centre'.

${ }^{21}$ http://www.institutkurde.org/en/conferences/kurdish studies irbil 2006/Presentation.html 
Scalbert-Yücel, Clémence and Ray, Marie Le (2006) 'Knowledge, ideology and power. Deconstructing Kurdish Studies', European Journal of Turkish Studies, Thematic Issue N ${ }^{\circ} 5$, Power, ideology, knowledge deconstructing Kurdish Studies, URL : http://www.ejts.org/document777.html To quote a passage, use paragraph (§).

within the field. The most important might be discordant political views that make it difficult to collaborate. Another might be the degree of 'scientificity' accorded to the work produced as certain Institutes' visions and works may strongly reflect nationalist feelings. Thus, it appears that the field is not strictly unified and that dissension does exist on several matters: who can belong to it and with which kind of works? What are Kurdish Studies? It seems that Institutes such as the KIP have managed to gather the most famous scholars, and it is difficult today to avoid participating in some scholarly activity of the Institute. That implies that it has appropriated a scientific vision of the 'Kurdish Studies' and has been careful, in this matter at least, not to cater to nationalist views. The field of Kurdish Studies has then been concretely built, with leading institutions (the KIP and few universities) and with other more marginal institutions (as the WKI or BGFK). Other institutions, though they argue they foster Kurdish Studies (such as the IKI), are made invisible and remain clearly outside the 'scientific field of Kurdish Studies' and have no contact with the first group.

[35] Kurdology emerged first as a multidisciplinary field of research within the Oriental Studies in Russia and in the USSR. During the $20^{\text {th }}$ century, in the USSR, it grew as an autonomous field as, for example, Iranology and Turcology had grown before it 22 . Special sections of Kurdish Studies do exist in Leningrad and Yerevan, in Paris and today in Exeter. Today these university sections are working more or less intensively, with more or less resources. All of them are linked to the non academic Kurdish institutions of research ${ }^{23}$. They link the field together and open it, when it is possible - as nowadays in Iraqi Kurdistan - in the Kurdish lands. The object of such a field of research is primarily language and literature - indeed works on language opened the 1st World Congress in Erbil, and studies on Kurds first started with the study of their languages - and all the range of disciplines within which Kurds are studied. The object is the Kurdish people. This field of investigation crosses others that are disciplinary or national, or both (Bozarslan 2006). This field explicitly goes beyond the field of university research. On the one hand, it is led by non academic institutions located outside Kurdistan, in Europe or in the USA and it includes independent researchers, journalists and writers. On the other hand, the aim of

22 Though Kurdology (as Turcology or Iranology) is characterized by its multidisciplinarity, it is sometimes argued that it constitutes a discipline on its own (see http://www.institutkurde.org/en/conferences/kurdish_studies_irbil_2006/Presentation.html)

${ }^{23}$ It is also necessary to mention here the importance of another research producer in the West, but also in Turkey: NGOs. For a long time, they were the only one to go into the field - in very difficult conditions - and to make observations, to collect data and publish them while academics made use of theses sources and data in the Occident. They must not be forgotten as one of the important sites of knowledge production. 
Scalbert-Yücel, Clémence and Ray, Marie Le (2006) 'Knowledge, ideology and power. Deconstructing Kurdish Studies', European Journal of Turkish Studies, Thematic Issue N ${ }^{\circ} 5$, Power, ideology, knowledge deconstructing Kurdish Studies, URL : http://www.ejts.org/document777.html To quote a passage, use paragraph (§).

developing scientific research about Kurds seems sometimes to go beyond the strict scientific ones. In this framework, the task of the academic scholars is ambiguous and multi-folded. Kendal Nezan describes the works of the academics as such: 'By choosing to interest yourselves in the Kurds, to make them known, to denounce the official state lies regarding them, you have [...] been a credit to the humanist traditions of science in a difficult context'24. The researchers on Kurds are seen as opposing the official ideology and policies of the states denying the Kurds and they do much in asserting the existence of the Kurds. They play, by their mere existence, a political role.

\section{Kurdish politics and the stake of knowledge: importance of kürdoloji}

[36] What is called kürdoloji is also given a great importance among Kurdish nationalists and activists' circles. Here is Vanly's definition: 'We can define Kurdology as all the studies done on Kurds, their history, their language, their country, their economic and social structure, the national movement and presenting an obvious scientific guaranty. It is then impossible to insert in Kurdology the libellous or pseudo-scientific works' produced within the states' ideologies' (Vanly 1970: 21). Kurdology, with an obvious anachronism, is supposed to have emerged at the end of the $18^{\text {th }}$ century (Rohat 1987, Blau 1983). The date given by Rohat, which is the most often referred to, corresponds to the work of Maurizio Garzoni on Kurdish grammar and vocabulary published in Roma in 1787. This author is often referred as the 'father of Kurdology'. What is the stake of such dating of the birth of Kurdology? It is certainly related to historiography writing since it sets off the ancientness both of Kurds and of the interest of the researchers in them. The terms of kürdoloji or of kürdolog are today frequently used in Turkey to refer to all academic researchers dealing with Kurds. The term referring to the ethnic name of Kurds stresses the existence of a separate people who is the object of a specific discipline. For sure, European works are very important for the Kurdist movement since they are said to provide legitimacy to their own works and to feed political demands. Then, since the first steps of Kurdish nationalism, the importance of publishing European research on Kurds is stressed 25 . The same process has taken place and has been studied for Turkish

$24 \mathrm{http}: / /$ www.institutkurde.org/en/conferences/kurdish studies irbil 2006/Presentation.html

25 The journal Jîn published in 1919 the declaration of the Kurdish group for the spread of knowledge. This declaration pointed out the need to translate European works about the Kurds. See Jin 10, February 1919, new edition prepared by M. E. Bozarslan (1985: 493). 
Scalbert-Yücel, Clémence and Ray, Marie Le (2006) 'Knowledge, ideology and power. Deconstructing Kurdish Studies', European Journal of Turkish Studies, Thematic Issue N${ }^{\circ} 5$, Power, ideology, knowledge deconstructing Kurdish Studies, URL : http://www.ejts.org/document777.html To quote a passage, use paragraph (§).

nationalism. Copeaux argues indeed that it is 'Western Orientalism that provided not only the decisive impulsion but also the authority upon which Turkish historiographical discourse relies' (Copeaux 1997: 72-73). As we see in the first Kurdish textual productions, the European references frequently used and quoted are used to give to the texts an objective tenor. This dimension has been striking since the works of Dr. Bletch: 'With regard to the Kurds, we do not want to present them by ourselves but to leave this task to the elite of European Orientalist authors who have best studied and known the Kurds and the Kurdistan by handing over to them' (Bletch 1930: 3). As in all contested identity, minority or national movements, the voice of the exterior - and then supposed scientific and impartial - academic is accorded much importance as it grants legitimacy to the discourses produced' and even contributes to their elaboration (Massicard 2002). The external discourses are even more important since the academia of the countries where they lived were most often denying the existence of the Kurds as Kurds. We will deal now with the studies produced about Kurds and Kurdistan within Turkey, studied here as a specific case.

\section{Studies on Kurds and Kurdistan: a taboo in Turkey?}

[37] The object is not here to produce a sociology of the academia and intellectuals in Turkey, a sociology that has yet to be done. Few works deal with the Turkish university and its relationships to power: among them we can mention Ali Arslan (2004), and articles of the special issues of Birikim (2001) and Toplum ve Bilim (2003) on Turkish universities. Very good studies of nationalism - and its relationships with science and hence with the educational and academic world - have already been done (Copeaux 1997; Taşkın 2001). These works argue that the university, as other Turkish educational institutions, is an organ used to train good citizens and to spread national culture and even nationalism (Copeaux 1997: 83; Arslan 2004: 58-159). The absence of autonomy of these institutions, especially since the 1980 Coup ${ }^{26}$, has to be kept in mind. The Law 2547 of 1981 on higher education

26 Tuncay (1983) argues that university and university staff was controlled by the state from 1909 to 1946 and even more since the promulgation of the Higher Education Council (YÖK Yüksek Öğretim Kurulu) in 1981. The 1980 military coup was followed by an extreme re-centralization of the academic institutional system and the strict realignment of works on the official ideology, itself in redefinition (with the promotion of the Turkish Islam Synthesis). The YÖK received the powers and responsibilities to govern all Turkish universities. It also led to a policy of opening universities in the provinces with a mission of enlightenment, westernisation and modernisation (Aktay 2001: 94). It approves the creation of departments and sections within departments. It 
Scalbert-Yücel, Clémence and Ray, Marie Le (2006) 'Knowledge, ideology and power. Deconstructing Kurdish Studies', European Journal of Turkish Studies, Thematic Issue N ${ }^{\circ} 5$, Power, ideology, knowledge deconstructing Kurdish Studies, URL : http://www.ejts.org/document777.html To quote a passage, use paragraph (§).

set out the aim of the university as the following: loyalty to Atatürk nationalism and to Atatürk's reforms and principles, being in harmony with the national, ethical, human, spiritual and cultural values of the Turkish nation, putting the common good above the own personal interests and having full devotion to family, country and nation, etc. (Williamson 1987: 207-208). In the 1980s, compulsory courses on Atatürk's principles and on the history of the Turkish Reforms were introduced. With no freedom of thought and expression, and seeped in nationalism, academic science cannot be far from dogma, as states İsmail Beşikçi in Bilim Yöntem (1991).

[38] Since the foundation of the Republican university, science has been used to serve ideological production, and academics are involved in ideology production. Shortly after its creation in 1933, the first Republican university, Istanbul University, and its scientific personal were to take their place in the consolidation of the newly-born Turkish Republic and nation, and the dissemination of its underlying ideology. Between 1935 and 1945, a series of conferences were held both at Istanbul University, with the active participation of professors from the Ankara Language and History-Geography faculty as well, and in the People Houses founded all over Turkey. The themes of these conferences were, as Biriz Berksöy (2000) argues, to conform to the ideological interests and policies pursued at that time by the single-party in power, the Republican People's Party. The faculties were regularly reminded that 'the high interests of the Turkish nation and the Turkish Republic rule all over the professorships of the University' and scientific works in the Humanities would notably have to be 'enlightened' by the productions of the Turkish History and the Turkish Language societies ${ }^{27}$. These institutions, that have been created to cultivate the idea of Kemalism, are the promoters of the Turkish History Thesis and the Sun-Language Theory, which presented the Turks as the source of all great civilizations ${ }^{28}$. It is the first 'scientific theory' to be produced by the academics and appropriated by state ideology. Later on, the Turkish Islamic synthesis and all the theories stressing on the Turkishness of Kurds will emerge.

is responsible for the appointment of deans and faculty while the President of Turkey chooses the director of each university (elections are forbidden by the 1982 constitution). Amended more than 20 times from 1982 until today, this council has been regularly criticized regarding the lack of academic freedom in research and teaching and the fact that rectors and deans of faculties were no longer elected by the teaching staff but directly chosen by YÖK.

${ }^{27}$ Opening speech of the University rector, Cemil Bilsel, for the 1936/37 University conferences. Quoted by Berksöy (2000: 41-53).

28 About these theses see Ersanlı-Behar (1992) and Copeaux (1997); about their relationships with the Kurdish issue, see Beşikçi (1977). 
Scalbert-Yücel, Clémence and Ray, Marie Le (2006) 'Knowledge, ideology and power. Deconstructing Kurdish Studies', European Journal of Turkish Studies, Thematic Issue N ${ }^{\circ} 5$, Power, ideology, knowledge deconstructing Kurdish Studies, URL : http://www.ejts.org/document777.html To quote a passage, use paragraph (§).

[39] Here we will present the Turkish works on Kurds and Kurdistan. We will present first the mainstream works about the 'Kurds'. They are two-fold: on the one hand, they aimed at denying the existence of such a people by 'proving' the invalidity of the use of the ethnic term 'Kurd'; on the other hand, they aimed at controlling a specific population that is thus stigmatised. Having shown that the taboo concerns, first, ethnicity, we will examine whether it has been possible to study the Kurds and the Kurdish region without taking into account the ethnic dimension. After this diachronic presentation, we will examine the very contemporary context in which new works emerged within the university but also still in its margins - as well as the works themselves.

\section{The ethnic dimension as a taboo}

[40] Mesut Yeğen points that, from the mid-1920s until the end of the 1980s, while denying the existence of the Kurds, the Turkish state 'nevertheless had to 'think', 'speak' and 'speculate' on the Kurdish issue. Hence many texts were produced regarding the Kurdish question (Yeğen 1996: 216). He argues, drawing from Foucault's Archaeology of Knowledge, that the Turkish state discourse was then caught up in a system of references to the existing and interacting discourses of westernization, centralization, nationalism and secularism. The Kurdish question was necessarily to be reconstituted in time as 'the demand for the Sultanate and Caliphate'; 'resistance of pre-modern social forms: tribes and bandits'; and finally, 'regional backwardness' (Yeğen 1996: 226). This discursive production undeniably contributed to shape the formation of knowledge on Kurds within and in the margins of the Turkish academic field as well. The common point of these discursive layers - that may have been combined differently in time - was to be silent on the ethno-political aspect of the Kurdish question (Yeğen 1996).

\section{Denying the otherness and the conflict}

[41] More than merely occulting the ethnic and conflicting dimensions, a great number of works aimed at denying the existence of such a group in Turkey. Scientific historical and linguistic works, using a large system of references, concluded that Kurds were Turks and that their language was a Turkish one. Such works, due to academics but also journalists or engineers really began at the start of the Republican era and were 
Scalbert-Yücel, Clémence and Ray, Marie Le (2006) 'Knowledge, ideology and power. Deconstructing Kurdish Studies', European Journal of Turkish Studies, Thematic Issue N ${ }^{\circ} 5$, Power, ideology, knowledge deconstructing Kurdish Studies, URL : http://www.ejts.org/document777.html To quote a passage, use paragraph (§).

carried on until the 1990s. New works on Turkey history support the idea of a continuation between Ottoman Empire and Republic of Turkey (Zürcher 1998). Fuat Dündar (2006b) also points out that this theory of the Turkishness of the Kurds started to be developed under the Union and Progress Government.

[42] The works of Kadri Kemal Kop $(1935,1938)$ are representative of the first period of the Republic. Today the historian Abdülhaluk Çay, professor at Hacettepe University, MHP (Milliyetçi Hareket Partisi - Nationalist Action Party) member of Parliament (elected in 1999) and member of the party's direction (elected in 1997), is well known, specifically to have emphasised the Turkish descent of the Newroz feast (Çay 1985) ${ }^{29}$. Çay and his works represent an important academic trend representative of the 1980s mainstream academic stance on the Kurds. This stance was represented by academics close to the power. Since there were no Kurds in Turkey, there was neither a Kurdish issue nor a Kurdish problem in Turkey. The only issue concerning Turkey was the issue of banditry and then, with the growing importance of PKK (Partiya Karkerên Kurdistan Kurdistan Workers' Party), of terror and separatism (bölücülük), largely due to both an imperialist Western and a socialist Russian plot to divide the country. The separatists are defined as Kürtçü whose strategy is to convince the eastern Turkish citizens they are not Turks but Kurds ${ }^{30}$. Then the role of the researcher is to demonstrate scientifically that the Kurds, contrary to what the separatists argue, are real Turks. These researchers - among them very important academics - both feed and protect the official ideology on different issues and, among them, on the Kurdish one. We can call them, as Taşkın does, 'missionary intellectuals' (Taşkın 2001b). The mission these intellectuals fulfil is also given to them by the state. The first very concrete example, concerning the Kurdish issue, goes back to 1961. At this time, the Barzani movement in Iraq was strong and much influenced the Kurds in Turkey who, little by little, started to be receptive to national and particularistic discourses and started to organise themselves within organisations and later political parties. The Turkish state then considered it important to spread again and to develop the negation of the Kurds. It clearly gave this task to science and its men. It is interesting to

${ }^{29}$ According to the author, Nevruz is part of Turkish traditions the enemy and separatist forces want to appropriate. His task, as a researcher is to shed light on these endangered elements of Turkish civilisation. According to him, Nevruz is celebrated in the whole Turkish world to commemorate the New Year's Day and the departure of the Turks from Ergenekon.

30 Illhan Akbulut, in his PhD thesis approved at Istanbul University in 1988 and published by Boğaziçi Press in 1990, defines as follow the Kürtçü: 'a person who defined itself as a Kurd, who, doing propaganda for Kurdish culture and working for Kurdish independence, wants to established a Kurdish state' (Akbulut 1990: 95). 
Scalbert-Yücel, Clémence and Ray, Marie Le (2006) 'Knowledge, ideology and power. Deconstructing Kurdish Studies', European Journal of Turkish Studies, Thematic Issue N5, Power, ideology, knowledge deconstructing Kurdish Studies, URL : http://www.ejts.org/document777.html To quote a passage, use paragraph (§).

look at the re-publication of M. Şerif Fırat's Doğu IIlleri ve Varto Tarihi (1961) prefaced by General Cemal Gürsel himself. According to the General, at the time President of the Republic of Turkey, it is necessary to reiterate, with scientific proofs, that the Kurds are 'mountains Turks'. It is necessary not to let any possibility to deny this. Scientific works, bringing scientific proofs, will help (Preface by Gürsel in Firat 1961: 3). This book was distributed free of charge to university professors, assistants, and student organisations, but also to journalists and writers and to school libraries (Beşikçi 1990a: 80-1).

[43] These works, purporting to prove the Turkishness of Kurds, were undertaken at least in part by academics. However, contrary to Armenian studies, there is no section in the Turkish university devoted to the Kurdish studies ${ }^{31}$. Moreover, except few publications by few universities (such as the publications of the Erciyes University), the publication of the books produced by academics on Kurds are rather published outside the university and mainly by the Boğaziçi Yayınları, a radical-right publishing house ${ }^{32}$, or by the Türk Kültür Araştırma Enstitüsü (Research Institute on Turkish Culture, TKAE)'s publishing house. This 'para-university institution', led first by Cemal Gürsel himself, played a major role in developing and spreading those 'scientific' works.

[44] The TKAE was established in 1961 under the protection of the president Cemal Gürsel, at the beginning under the Ministry of Foreign Affairs (Taşkın 2001b: 208). It is an 'unofficial institution' (Copeaux 1997: 95) that has, however, been backed by the state and was officially recognized as an institution of public interest in 1968. This institution published three journals: Cultura Turcica, Türk Kültürü (since 1962) and Türk Kültürünü Araştırmaları (since 1964). It also publishes books all dealing with Turkish culture and history whether in Turkey or abroad - indeed it was much inclined to Panturkism ideas (Landau 1995).

[45] The first editorial of Türk Kültürü, signed by the Institute (presided by İbrahim Kafesoğlu), presents the aims of the TKAE. It was established for 'scholarly research on the Turkish world in all its aspects as one entity, covering such wide-apart fields as history, ethnography, languages, art, social problems, philosophy, geography and economics, while the principle was to improve knowledge of all Turks, in order to strengthen the

\footnotetext{
${ }^{31}$ As the Kurdish question, the Armenian one is defined in Turkish official discourse in term of terrorism, supported by the Occident. The stress is often put on the massacres of Turks by the Armenians during the First World War.

32 Radical right parties like MHP also consider it very important to have academics in their fold. Özçınar Zekai, 'MHP'li Milletvekillerini Bakanlık Heyecanı Sardı', Zaman, 01.01.2002.
} 
Scalbert-Yücel, Clémence and Ray, Marie Le (2006) 'Knowledge, ideology and power. Deconstructing Kurdish Studies', European Journal of Turkish Studies, Thematic Issue N5, Power, ideology, knowledge deconstructing Kurdish Studies, URL : http://www.ejts.org/document777.html To quote a passage, use paragraph (§).

Turkish nation and its national ideals' (Landau 1995: 162-3; he quotes Türk Kültürü 1, 1962). The Institute is a scholarly body, and members and writers in the journals are often prominent academics. One of the recurrent themes of the Türk Kültürü's writers was, as stated by Taşkın (2001b: 181), the 'sublimation of scientism' (Kafesoğlu 1968: 274-277). Landau added that though the scholarly standards were usually maintained, the choice of the topics as well as the writers was influenced by the political commitment of the journal (1995: 163). The discourses produced by the institute are nationalist-scientific; or nationalist, scientifically fed. Taşkın talks about a 'scientific nationalism' (ilimci milliyetçilik) (2001a: 75). Indeed, as Copeaux states (1997: 100), the journal is not only a cultural and scientific one. It has played an important role in spreading (but also building) the Turkish Islamic synthesis, the ideology of panTurkism and anticommunist views ${ }^{33}$. We can follow Landau by saying that the TKAE is a 'Turkist and nationalist body' (Landau 1995: 162). Again, slightly modifying Landau's words, one can argue that Türk Kültürü is probably the best example of a combination of nationalism and scholarship ${ }^{34}$. More than being only the distributing agent of the official ideology, these scholars are involved in its shaping process. Ideas produced were then largely taken over by radical right parties and by the state (as shown by the appropriation of the Turkish Islamic synthesis by the military leadership in the 1980s)35. They were also gatekeepers of the official ideology using scientific methods to protect it from all kind of attacks (becoming more important in the 1980s with the growing of Kurdish insurgency). TKAE contributed strongly indeed to produce, reinforce and spread the official discourse produced about the Kurds. First published in the 1930s, the works representative of the official ideology on this matter have been reprinted during political crisis, notably in the 1960s and then in the 1980s. After the military coup in 1980, TKAE started publishing a high number of short books according to which Kurds do not exist. According to Peter A. Andrews (1989: 36), the Institute had published fifteen titles of this kind between 1982 and 1984; Türk Kültürü, within this period, published a large number of articles about 'Kurds'. All the theses produced by academics like Abdülhaluk Çay or Tuncer Gülensoy (a linguist) and published by the TKAE and Türk

\footnotetext{
${ }^{33}$ Socialist/Marxist thinkers were accused of 'anti-scientifism' by those thinkers.

${ }^{34}$ Landau's original words are 'the best example of a combination of moderate pan-Turkism and scholarship' (Landau 1995:162).

35 Members and close relations of the TKAE had gathered in the Aydınlar Ocağı, which played an important role in building the Turkish Islam Synthesis.
} 
Scalbert-Yücel, Clémence and Ray, Marie Le (2006) 'Knowledge, ideology and power. Deconstructing Kurdish Studies', European Journal of Turkish Studies, Thematic Issue N ${ }^{\circ} 5$, Power, ideology, knowledge deconstructing Kurdish Studies, URL : http://www.ejts.org/document777.html To quote a passage, use paragraph (§).

Kültürü were accorded great legitimacy ${ }^{36}$, while theirs authors were accorded good academic positions at a time where the purges within the university were strong ${ }^{37}$.

[46] Research produced within the academy often aimed at producing applied knowledge: indeed they produced knowledge on the region and its population both in order to reinforce the state ideology and to prepare a state intervention (concerning populating, modernisation, development and territorial integration). The political implications of scientific discourse is well observable in Turkey but is characteristic of a large part of the colonial (Said 1980) or Soviet knowledge (Roy 1997) as ethnographic and anthropologic researches 'have a strictly political function and are manipulated by the powers' (Donegani 2006 : 13; see also Said 1980). The Russian Kurdology mentioned above as well as the papers of Jordi Tejel and Fuat Dündar in this issue offer a comparative view of the use by the states (mandatory French in Levant and Ottoman Empire) of ethnology and science. In the Levant case, the 'Kurdolog' researched the Kurds in order to know and control them; in close relation with the Kurdish nationalists, they also participated in the building of a specific Kurdish national identity (Tejel 2006); on the other hand, Unionist ethnologists and sociologists studied a specific population perceived as such in order to integrate them, to make them same (Dündar 2006a).

Knowledge to control and integrate: a paradoxical acknowledgment of otherness

[47] As shown by Fuat Dündar, the first works on Kurds and Kurdish tribes in the Ottoman Empire were very practical and aimed at finding a way to integrate or even to assimilate these populations (2006b, 2006a). This went on during the Republican era: experts were sent to the East to produce reports about the social organisation, the ethnic or racial characteristics of the population. It led to concrete state action as shown by the plan of Reform of the East in the 1920s (Bayrak 1993). At the end of the Ottoman Empire

36 Suat Illhan, head of the AKDTYK (Atatürk Kültür, Dil ve Tarih Yüksek Kurumu), founded by the 1982 Constitution, was a member of the military apparatus. He frequently referred to those studies. He wrote: 'Without reading works of Professors Abdülhaluk Çay and Tuncer Gülensoy, producing ideas on Kurdish would be erroneous. Those studies initiated by the head of the Turkish Historical Association - Prof Yusuf Halaçoğlu - started producing interesting conclusions. The scientific works draw Kurds near to Turks' (Taşkın 2001b: 365). The author quotes Illhan (1999: 289).

37 If the purges are a recurrent phenomenon in Turkish universities' history, the main one followed the 1980 coup: several thousands of civil servants had to leave the universities with the purges organised according to the law 1402 passed in 1983. Left-wing staff was excluded and replaced by right-wing academics very close to the ideology of the State. As Zafer Toprak underlines: 'the 1980 military intervention was against the university, whereas the 1960 one was for the university. Academics collaborated with it. The first target of 1980 was the university. There is no intellectual who supported the 1980 Coup' (Monceau 2005: 115). 
Scalbert-Yücel, Clémence and Ray, Marie Le (2006) 'Knowledge, ideology and power. Deconstructing Kurdish Studies', European Journal of Turkish Studies, Thematic Issue N ${ }^{\circ} 5$, Power, ideology, knowledge deconstructing Kurdish Studies, URL : http://www.ejts.org/document777.html To quote a passage, use paragraph (§).

and after 1909, the sociologist Ziya Gökalp conducted important works in the Diyarbakir province. Gökalp underlined that in order to find a 'treatment' it was necessary to establish a 'diagnostic' (Fuat 2006b: 362). A short time after the 1913 Coup, Talaat Pacha put Gökalp in charge of mobilising scientific forces to discover Anatolia, this unknown land (Dündar 2006b). Gökalp, in his time, had already underlined that the assimilation took place only in the cities. A necessary step towards national integration was, then, the settlement of the nomadic tribes. Studies on eastern and southeastern (nomadic) tribes much stigmatised as symbolising backwardness in a very clear way - went on later, particularly in the frame of the Project of Southeastern Anatolia (Güneydoğu Anadolu Projesi, GAP). These studies were conducted in order to prepare the state for investment and intervention in the region.

[48] A more contemporary example of expert works produced by academics for state use are thus those made in the context of the elaboration of the GAP's Master Plan in the 1980s. With this plan, in 1989 the GAP Project became a project of regional development. The transformation of the GAP in a regional development project - which aimed at developing, modernising and changing not only the economic but also the social structure of the region - was an important step in the development of social science research (and fieldwork) in the region. Different university staffs were directly employed by the GAP administration or by the State Planning Organisation (Devlet Planlama Teşkilatı, DPT) under the directorship of which the GAP is led. A good example is the sociologist Ahmet Özer. He obtained his $\mathrm{PhD}$ degree in sociology with a thesis entitled Socioeconomic, Cultural and Politic Dimensions of the GAP in 1995 at Hacettepe University. At the same time, as a sociologist, he conducted fieldwork for the GAP and DPT in the GAP region. In his book, written following this two years fieldwork in Urfa, he describes the economic and social structure of the region. The main conclusion is that the structure is traditional and has to and will be modernised (Özer 1994: 88-89). The GAP will be a very strong incentive. By modernising the economic sector, the social one (which is characterised as tribal and paternalist) will change. The question of the tribe is a 'problem' to be 'solved' (Özer 1994: 150). The GAP Master Plan is very close to the conclusion of the author and proposes a social change on the same scheme ${ }^{38}$. In such works, the question of ethnicity is never mentioned. The question of the conflict is only briefly mentioned: solving it is one of the conditions to develop and modernise the region.

\footnotetext{
${ }^{38}$ See the objectives of GAP on http://www.gap.gov.tr/gap eng.php?sayfa=English/Ggbilgi/ghedef.html
} 
Scalbert-Yücel, Clémence and Ray, Marie Le (2006) 'Knowledge, ideology and power. Deconstructing Kurdish Studies', European Journal of Turkish Studies, Thematic Issue N ${ }^{\circ} 5$, Power, ideology, knowledge deconstructing Kurdish Studies, URL : http://www.ejts.org/document777.html To quote a passage, use paragraph (\$).

[49] Another step of the research conducted within the frame of the GAP began in the early 1990s. These studies were conducted under the GAP's Administration of Regional Development and the results of the surveys were used in the preparation of a Social Action Plan. They have built a framework for the forthcoming projects (ÖzokGündoğan 2005: 99). Researchers and even universities worked in close cooperation on the GAP region in the fields of economy, ecology, agronomy as well as sociology and ethnology. Institutes working on the GAP were founded within universities: the Middle East Technical University's GAP Research and Practice Centre was founded in Ankara and the Dicle University's GAP Research and Practice Centre was founded in Diyarbakır in 199039. As theirs names suggest, these centres have not only scientific but also practical functions. In Ankara, lectures and courses are organised on the issues related to the GAP, students are directed toward master and PhDs on these issues. The Ankara Centre works in close relationship with public institutions, which also give directives. The Centre also has to think about the ways the projects have to be conducted. Quoting the GAP official website, ÖzokGündoğan states that 'the overall objective of these surveys was 'to develop a better understanding of the socio-economic and cultural make-up of the region; to identify the needs, expectations and tendencies of the society in general and specific social groups in particular, and to identify the special target groups [...] of development' (2005: 100). Those surveys highlighting the 'problem' can legitimate the intervention of the state. ÖzokGündoğan argues that 'the Kurds and the Kurdish-populated regions became observable, quantifiable, and hence controllable objects of this novel interest' (2005: 100). ÖzokGündoğan also argues that these surveys never mention either the ethnic dimension or the conflict between the state and the PKK and therefore depoliticize the question.

[50] However, this great need for data on the region provides researchers with the chance to go there and to conduct fieldwork within reasonably good conditions. Clearly, the researcher is progressively gaining more and more autonomy. And, since the late 1990s, a great deal of new works on GAP now focus on the project and on the relationships between the centre and its peripheries, and not on the periphery as a site in need of modernization and integration 40 . We can give the example of Neşe Özgen, a sociologist at the Aegean University. She first conducted fieldwork in the southeast in the İil area

39 Other centres have been founded in Gaziantep University (GAPMER) or in Harran University (1993). The latest mainly undertake agronomic researches (see http://www.harran.edu.tr/gtarim/).

40 Look for example at the Boğaziçi team's works and at the special issue of New Perspective on Turkey $\left(\mathrm{n}^{\circ}\right.$ $32,2005)$ on the Kurdish question. 
Scalbert-Yücel, Clémence and Ray, Marie Le (2006) 'Knowledge, ideology and power. Deconstructing Kurdish Studies', European Journal of Turkish Studies, Thematic Issue N${ }^{\circ} 5$, Power, ideology, knowledge deconstructing Kurdish Studies, URL : http://www.ejts.org/document777.html To quote a passage, use paragraph (§).

(department of Şırnak) in 1997. This project of regional development of Şırnak/idil (Şırnak/Idil Bölgesel Kalkınma Projesi) was directed by the Association for the support of Modern Life (Çağdaş Yaşam Destek Derneği, ÇYDD) in collaboration with the United Nation Development Program (UNDP) and the Association of Sociology. In 2000, Neşe Özgen also started to work for the Plan of Regional Development of the GAP, again in collaboration with the UNDP, but rapidly put an end to this experience. Through these different fieldworks in the south-east, she came to new questions, like 'what does it mean to be a citizen on the frontier'41. She is currently developing what she calls a 'sociology of the frontier' (sınır sosyolojisi), a project she conducts on her own ${ }^{42 i v}$.

[51] Looking at these works is very instructive. First it enables us to see how much the researcher was necessary for the state to build its policies (integration, development policies, etc). It also shows - and we will come back to this - that research on the region was, though under specific constraints, possible. At least it shows how the region was (and is still) stigmatized as backward. This backwardness is clearly symbolised by the tribal social organisation, a subject that draws specific attention (Yeğen 1996).

\section{Studies on Eastern Turkey}

[52] We can then wonder what is the place of İsmail Beşikçi researching on the Alikan tribe in the 1960s? Is he the first? Is he the last to undertake academic works on Eastern Turkey? It seems that works on what we know to be the Kurdish area have always been possible to undertake if they aimed at denying the existence of this ethnic identity or if ethnicity and conflict were not mentioned. They were produced either by local nonacademic writers or by students or academics working in the region ${ }^{43}$. We had already

41 Interview with Neşe Özgen, '30 tane koyun kesemez insan bir anda', http://www.savaskarsitlari.org/arsiv.asp?ArsivTipID=6\&ArsivAnalD=16678\&ArsivSayfaNo=3

42 The first project about the Southeast she was involved in was the 'Project of regional development of Şırnak/Idil (July 1997-November 1997). She was the director of the project under the direction of the Association for the Support of Modern Life (Çağdaş Yaşam Destek Derneği, ÇYDD) in collaboration with the United Nation Development Program and the Association of Sociology. The second project she got involved in was the Plan of Regional Development of the GAP led by GAP-BKI (GAP-Bölge Kalkınma İdaresi) and the United Nation Development Program. She participated in this project as a sociologist (July-December 2000). The third project she conducted personally, supported by the Aegean University and TÜBITAK, resulted in the publication of the following book: Toplumsal Hafızanın Hatırlama ve Unutma biçimleri Van-Özalp ve 33 Kurşun Olayı, Tüstav, Istanbul, 2003.

43 In-depth research on these works is still to be conducted. However, a quick look at the licence and doctorate thesis and journals produced in Southeastern Turkey's universities is instructive. These universities were opened late, from the 1970s and mostly in the 1980s. Most of the researches their students undertake are done on the region where the university is located. 
Scalbert-Yücel, Clémence and Ray, Marie Le (2006) 'Knowledge, ideology and power. Deconstructing Kurdish Studies', European Journal of Turkish Studies, Thematic Issue N ${ }^{\circ} 5$, Power, ideology, knowledge deconstructing Kurdish Studies, URL : http://www.ejts.org/document777.html To quote a passage, use paragraph (§).

mentioned that some studies have been conducted since the 1980s within the frame of the elaboration of the GAP Master Plan, which produced important knowledge and data about the region while avoiding speaking about the 'Kurds' or even of the 'conflict'. Before that, a few works on the region deserve attention. Among them, the better-known is the research of İsmail Beşikçi. His doctoral thesis on the Alikan nomad tribe at the Ankara University (1969a) can be included in this kind of works although it is more complex to read and will lead Beşikçi in his second work (1969b) to talk openly about the Kurds and ethnicity.

[53] While, in the 1960s, the country was undergoing rapid social and economic change, a progressive social scientists' stand emerged. The early İsmail Beşikçi was in many ways representative of this group, strongly interested in searching for the causes of inequality and its solutions, notably by reforms from above. As Martin van Bruinessen underlines, 'in the course of the decade, many of them came to adopt Marxism in one form or another as a framework for explanation' (Van Bruinessen 2003-4). Looking at their readings of the region however, they were still - like the left movements at broad in the late 1960s -- very much ingrained in the Kemalist anti-feudal rhetoric. The Kurdish tribal and religious leaders' power was then conceived as the main reason of the region backwardness, it being kept out of 'modernity'. His work then rests on a developmentalist frame (as will do the studies on GAP later) that largely shared Kurds themselves at the time (Bozarslan 1966). The researchers then focused on the resources of the state and their unequal repartition, not on the ethnic or national issue. The issue Beşikçi deals with (the nomadic tribe) is also very representative of the developmentalist views according to which the tribe is an obstacle to development. It is interesting to note also that Beşikçi does not want his work to be considered as a monographer but as a work leading to theoretical progress. Moreover, Beşikçi states that he wants his research to have concrete application and to give elements to help to solve the problems of the region.

[54] Though Beşikçi comments on 'the Kurdish Alikan tribe' - he argues that he uses the term of 'Kürt' to ease the definition of the object - and though he mentions the existing debates and theories on ethnicity, he states that he does not take position dealing with the Kurdicity or 'Turkishness' of Kurds, and does not insert himself into this debate: it is not the object of his work and it does not help to comprehend the 'social change' he deals with (Beşikçi 1969a: 8). His references coming from the mainstream academics (Farhettin Kırzıoğlu, Mehmet Eröz) are only used to give a presentation of mainstream 
Scalbert-Yücel, Clémence and Ray, Marie Le (2006) 'Knowledge, ideology and power. Deconstructing Kurdish Studies', European Journal of Turkish Studies, Thematic Issue N ${ }^{\circ} 5$, Power, ideology, knowledge deconstructing Kurdish Studies, URL : http://www.ejts.org/document777.html To quote a passage, use paragraph (§).

theories but not to support his argumentation. However, not to take a position is already to take one in a time where, as underlined, the academics were strongly fostered to feed the official theory of the Turkishness of the Kurds. Then, we can argue that Beşikçi aimed to describe as squarely as possible the reality of the region other researchers often hide. That is certainly his love for science and intellectual honesty that led him to talk about the ethnic dimension of the region and to the formulation of the 'Question of the East' in Doğu Anadolu'nun Düzeni (1969b), a work he wrote when he was still an assistant in Erzurum's Atatürk University and which put an end to his academic career (Beşikçi 1988). 'By emphasizing that ethnicity was a relevant fact of social life, by treating Kurdish nationalism as just as self-evident a social phenomenon as Turkish nationalism and by questioning the anti-feudal and therefore progressive character of Kemalism, Beşikçi struck at the roots of the worldview of Kemalists as well as Turkish socialists' (Van Bruinessen 2003-4). He was transforming what was then the 'Eastern question' in terms still unacceptable in regards to the intellectual climate, and more specifically to the mainstream academic discourse of the 1960s and 1970s in Turkey. Indeed Beşikçi states in this book that the 'Question of the East' was not only an economic question, not only a question of development but also an ethnic one (1969b, republishing in 1992: 34) and the second part of the book clearly deals with the emergence of a national question. It also deals with the state policy towards Kurds. As Van Bruinessen wrote, 'this was the first serious attempt to write a social and political history of the Kurds in Turkey, and it was long to remain unsurpassed' (Van Buinessen, 2003-4). But starting distancing himself from the Kemalist perspective to develop a systematic critique of its ideology and practice ${ }^{44}$, Beşikçi found himself isolated within the academic establishment and, following the 1971 military intervention and his 3 years imprisonment, would never find an academic position again.

[55] After that, works on the Southeast, and on the southeastern tribes for example, went on. However, it was necessary for the authors to quote the legitimate works denying the existence of Kurds and to take part, on the right side, in the debates, in order to receive their $\mathrm{PhD}$. It was neither possible for the authors to talk about 'Kurdish tribe' as

44 Ismail Beşikçi wrote Bilim Yöntemi in 1978 in order to criticise the close relationships between Turkish academia and state ideology. In 1992, in the preface of the new edition of Doğu Anadolu'nun Düzeni, he felt the need to apologize for his first writings, still very much influenced by the ideology of the state. 
Scalbert-Yücel, Clémence and Ray, Marie Le (2006) 'Knowledge, ideology and power. Deconstructing Kurdish Studies', European Journal of Turkish Studies, Thematic Issue N5, Power, ideology, knowledge deconstructing Kurdish Studies, URL : http://www.ejts.org/document777.html To quote a passage, use paragraph (§).

Beşikçi had done nor to talk about mere 'tribe'. The authors had to talk about 'Turkish' or 'Turkmen' tribe ${ }^{45}$.

\section{Can we speak of a Turkish Kurdology today?}

[56] It is not before the early 1990s that ethnicity could be openly discussed and became a framework of explanation among scholars in Turkey. This does not mean that the above-described discursive field lost its relevance within the academic field. Would it be that some academics were able to add new layers of meanings, to inscribe themselves into other systems of references from the 1990s on? If so, what practically allowed that? What does this mean concretely in terms of subject, methods and practices of research? Would it be the sign of a notable re-composition of Turkish academia?

\section{Conditions of the opening}

[57] In 1990, President Turgut Özal, during a trip in southeastern Turkey, publicly recognised the existence of Kurds and of a Kurdish issue. It marked the first opening towards the challenge to the official thesis affirming the non-existence of Kurds. In 1991, law 2932 of 1983 was amended to make the private use of non-Turkish languages possible. This law also enabled, although indirectly, publication in Kurdish. New publishing houses were founded. They not only published in Kurdish but also published many documents and studies on the Kurds. The role of these publishing houses is fundamental to understanding the rise of publications concerning the Kurds in Turkey. However in the 1990s, repression was very strong against those publishing houses (as shown by the numerous trials Yurt Publishing House faced for Beşikçi's books for example). By the end of the 1990s, the situation became quieter, and it is today possible to publish almost everything. Publishers, however, are often brought to trial but do not face such heavy jail sentences any more. The turn of the century was marked by the arrest of Abdullah Öcalan (in February 1999) and, officially, by the lifting of the state of emergency in the southeastern regions, completed in 2002. On a regional scale, Turkey is engaged more strongly in the process of European integration, which pushes the country towards an acknowledgment of its Kurdish population. This situation gives rise to more opportunities to conduct research more freely and to speak more openly on the issue. Doing fieldwork also

\footnotetext{
${ }^{45}$ See the Licence and $\mathrm{PhD}$ thesis written in Fırat University for example.
} 
Scalbert-Yücel, Clémence and Ray, Marie Le (2006) 'Knowledge, ideology and power. Deconstructing Kurdish Studies', European Journal of Turkish Studies, Thematic Issue N5, Power, ideology, knowledge deconstructing Kurdish Studies, URL : http://www.ejts.org/document777.html To quote a passage, use paragraph (§).

became easier with both the end of the conflict and the lifting of the state of emergency. In the 1990s, research was first conducted by associations of the 'civil society.'

[58] According to Erichsen (1998: 207-210), the role of NGOs in the field of research has been growing since the 1980s, in part due to the lack of resources of the state and to the vacuum caused by its withdrawal from some spheres of public life. Above all, during the 1990s, the war was raging and polarisation was extremely strong. War was also raging in the media, which we can consider as participating in a specific form of knowledge production, and the media was divided into two parts, each one backing each side. Early in the decade, the associations of civil society were the first to denounce this war and to speak about the Kurdish issue and the needs to solve it. According to Groc (1998), associations of civil society emerged in the late 1980 around the promotion of democracy and human rights and around the Kurdish issue. A wide range of associations and foundations, from human rights associations to business associations, became involved in discussing the issue and its solution. Along these lines, the Turkish Human Rights Foundation (Türkiye Insan Hakları Vakfı) and the Human Rights Association (Insan Hakları Derneği) were early to pick up the Kurdish issue. IHD reports, all the more valuable because the association was present in the southeast at the height of the conflict, became widely used sources and gave a visibility to hidden or misrepresented events.

[59] Works produced by Helsinki Citizens Association (Helsinki Yurttaşlar Derneği, HYD) were the first to lead action in order to promote peace and to find a solution to the Kurdish issue (Taciser 1992). HYD, a member of the Helsinki Citizens Assembly ${ }^{46}$, is a non-governmental association that was founded in September 1993. It works on fundamental rights and freedoms, peace, democracy and pluralism. It undertakes actions to enable citizens to discuss about their societal problems by bringing together the different sides. It has organised different activities around the following themes: minority rights and multiculturalism, civic approaches to conflicts, rule of law, human rights and civic participation, local democracy and civil society and the EU integration process. It has been among the most important of the NGOs in organizing events concerning the Kurdish issue. A recent and important step was the organisation of a Conference entitled Looking for a Civil and Democratic Solution I. The Kurdish Question in Turkey (Sivil ve Demokratik

46 The world 'Helsinki' refers to the Helsinki Final Act (1975), 'which has founded the basis for the improvement of the necessary conditions of a peaceful environment in Europe, proclaimed human rights to be a common value that every community had to respect throughout the world'. www.hyd.org.tr 
Scalbert-Yücel, Clémence and Ray, Marie Le (2006) 'Knowledge, ideology and power. Deconstructing Kurdish Studies', European Journal of Turkish Studies, Thematic Issue N ${ }^{\circ} 5$, Power, ideology, knowledge deconstructing Kurdish Studies, URL : http://www.ejts.org/document777.html To quote a passage, use paragraph (§).

Çözüm Arayışları I. Türkiye'nin Kürt Meselesi), in collaboration with the Empati Grubu, in Istanbul in February 2006. This conference gathered together academics, politicians, journalists, etc. Though it took place in Istanbul at the private University of Bilgi, the conference was organized by the two mentioned associations ${ }^{47}$. However, the place where it was held and the fact that many participants were scholars attracted a great deal of attention. It was the first time the Kurdish question had been discussed within an open and academic context48: 'To be able to speak and discuss freely... To be able to do that, especially in an academic environment... To drive the issue from there to politics' wrote Hasan Cemal49.

[60] It is not only among the supporters of fundamental rights and pluralism that the Kurdish question has been discussed; it also interested the economic sector early on. Amidst the growing conflict in the southeast, in the 1990s, Doğu Ergil, professor of political science at Ankara University, conceived it both his 'civic duty' and an 'academic obligation' to try to understand what was going on and therefore, he designed a research project which aimed at studying the 'social conflict' and proposing 'solutions' other than the use of military power and violence. He met the president of the Turkish Union of Chambers of Industry and Commerce (Türkiye Odalar ve Borsalar Birliği, TOBB), himself a native of the eastern region, and interested in the opening of the region both to peace and business activities. The TOBB networks, including branches in the region but also close relations with the True Path Party (Doğru Yol Partisi, DYP) party structure and government actors, made it quite easier for Ergil to conduct survey in the Southeast. The main support Ergil found in Turkey during the 1995 survey and after its publication came from businessmen. He found again the same kind of support for the 2005 survey (Ergil 2006a). In his report Eastern Question. Diagnoses and Facts, the relatively traditional idea that Kurdish nationalism is fed by the economic and social backwardness of the region coexists with the acknowledgement of 'identity' as one component of the 'Eastern question'. Answering to an interview, he said he entitled his report 'Eastern question' and not 'Kurdish question'

47 Several teaching members of Bilgi University can in fact be found among the founders of the HYD.

48 İsmail Beşikçi quoted by Derya Sazak 'İmralı'daki Değil Dışarıdakiler Konuşsun', Milliyet, March 14, 2006. Beşikçi said that the Conference, held in a university, was an important step and that it softened the official ideology. Look also, for example, at Hasip Kaplan quoted by Nezahat Alkan 'Kürt Konferansı'nın Yankıları Sürüyor Çözum için bir Adım Daha', Birgün, March 14, 2006. Ümit Fırat and Murat Belge quoted by Hasan Cemal 'PKK, Silaha Veda Etmeli!', Milliyet, March 14, 2006.

49 Hasan Cemal 'PKK, Silaha Veda Etmeli!', Milliyet, March 14, 2006. 
Scalbert-Yücel, Clémence and Ray, Marie Le (2006) 'Knowledge, ideology and power. Deconstructing Kurdish Studies', European Journal of Turkish Studies, Thematic Issue N ${ }^{\circ} 5$, Power, ideology, knowledge deconstructing Kurdish Studies, URL : http://www.ejts.org/document777.html To quote a passage, use paragraph $(\S)$.

because it is a problem concerning Turkey as a whole ${ }^{50}$. According to Ergil, this report 'made a taboo subject debatable' and 'challenged' the official mentality that the Kurds are 'separatist'. Ergil was most heavily criticized for the report by both some actors within the political sphere who accused him of being a 'Kurd lover' or a CIA agent and by some within academia, some of whom accused him of not being sufficiently scientific ${ }^{51}$. Ergil went on in the field of civic society by founding his own, internationally backed, Foundation for the Research of Societal Problems (Toplumsal Sorunları Araştırma Vakfı, TOSAV), aiming to be a discussion forum between Turkish and Kurdish nationalists, to define the Kurdish issue and to take steps to find solutions. According to him, academic studies do have to get visibility in order to 'shape creative policies' (Ergil 2006a).

[61] Parallel to official discourses (see above) claiming to be scientifically argued, denying the existence of the Kurds, the Kurdist movement uses Western academic productions but also produces its own discourses and knowledge. Quoting the words of Elise Massicard on the Alevist movement, we can say that, in such a situation where Kurdish identity is subject to negation and unstable definition, knowledge is not only a 'symbolic capital' but also a 'first-plan identity resource' to 'reveal the origin and the meaning' of kurdicity (Massicard 2002).

[62] As in every nationalist movement, discourse on the past is used in order to explain and legitimate the present struggles. Historiography is actually very present in all aspects of Kurdish intellectual life (Bozarslan 2001: 47). This knowledge was produced first by political actors writing their memories or essays and by non-academic researchers (known in Turkey as araştırmacl-yazar) ${ }^{52}$. Their scope of investigation is often very wide as it does concern history but also language, folklore and so on. Studies are undertaken by individuals and published as books or articles in Kurdish journals. Kurdish cultural centres were also founded in the 1990s in Turkey. One example is the Istanbul Kurdish Institute, as mentioned above. The Institute stresses the importance of researching, collecting and presenting the aspects of Kurdish culture that have been destroyed. It proposes to product alternative documents to the official ones ${ }^{53}$. However the scientific character of the works

50 Yılmaz, Sinan, 'Ergil: the Report was my Duty as a Citizen', Turkish Daily News, August 10, 1995.

51 Demirsar, Metin, 'Ergil: Southeast Approaching Civil War Conditions', Turkish Daily News, September 7, 1995.

52 Indeed, these researchers writing on Kurdish history in committed journals are not 'university-trained' historians: Sıraç Bilgin graduated from the medical faculty in Diyarbakır, Cemşid Bender completed a PhD in law, Gürdal Aksoy graduated in law, etc. See Hirschler (2001: 149).

${ }^{53}$ See http://www.enstituyakurdi.org/modules.php?name=News\&file=article\&sid=3 
Scalbert-Yücel, Clémence and Ray, Marie Le (2006) 'Knowledge, ideology and power. Deconstructing Kurdish Studies', European Journal of Turkish Studies, Thematic Issue N ${ }^{\circ} 5$, Power, ideology, knowledge deconstructing Kurdish Studies, URL : http://www.ejts.org/document777.html To quote a passage, use paragraph (§).

can sometimes be contested as they are strongly involved in the production of a nationalist discourse $e^{54}$.

[63] All researchers on Kurdish nationalism (Bozarslan 2001, Hirschler 2001, Vali 2003b) have demonstrated that these nationalist discourses were built and used as a 'riposte' toward the official Turkish thesis ${ }^{55}$. Moreover, Kurdish historiography works were also often an 'inverted copy of the Türk Tarih Tezisi' (Hirschler 2001: 150). According to Bozarslan, though there were no 'Kurdish institutional tools' to build a scholarly history, Kurds 'could adopt the methods and postulates of Turkish state historians'. And that is what was often done: 'as its Turkish model, Kurdish historiography looked for the origins of the nation and of its ideal in 'ancient' history; origins which were then loaded with values to preserve and pass on' (Bozarslan 2001: 63). Origins of the Kurds were debated and go back, at least, to the Medes while the origin of the language goes back to the Avestic; Kurdistan is said to have always been a Kurdish land.

[64] It was at the end of the 1960s and even more in the 1970s that Kurds within Turkey started to publish and to write on their history, language and culture. This period corresponds to a period of semi-liberalisation in the country (and, as we mentioned above, of the Iraqi Kurdish movement which strongly influenced the Kurds in Turkey). Then, publishing houses and journals were founded and published this kind of work. At that time, works such as Beşikçi's, since Bilim Yöntem, were also a 'riposte' and proposed strict analysis of Kemalist policies, ideology and historiography, particularly towards the Kurds. All Beşikçi's works of the 1970s and 1980s constitute 'one of the first systematic efforts at a serious revision of republican history to appear in Turkey' (Van Bruinessen 2003-4). Mehmet Bayrak also published number of archiveal documents that could be used by researchers to criticize the Kemalist Kurdish policy, the official Turkish thesis and to produce a counterhistory.

[65] Looking to know itself but at the same time to get legitimacy to counter the official thesis, the Kurdist movement was the main way through which European academic works were introduced in Turkey, sometimes encountering great difficulties. The first

54 For example, Müslüm Yücel, in a still unpublished work analyses the historiographical views of the Kurdish Institute in Istanbul through a critic of the works of Feqi Hüseyin Sağnıç (who wrote about the 'Kurdish States') and Torî (who wrote about the Kurdishness of the Urarto or of Ayyubi State). See Torî (2001a, 2001b).

55 Vali argues that the genesis of Kurdish nationalism 'is the relationship of the self and other with the emergent Turkish, Persian and Arab identities in the early decades of the present century' (Vali 2003b: 104). 
Scalbert-Yücel, Clémence and Ray, Marie Le (2006) 'Knowledge, ideology and power. Deconstructing Kurdish Studies', European Journal of Turkish Studies, Thematic Issue N ${ }^{\circ} 5$, Power, ideology, knowledge deconstructing Kurdish Studies, URL : http://www.ejts.org/document777.html To quote a passage, use paragraph (§).

example is the one of Van Bruinessen's Agha, Shaikh and State. By the end of the 1980s (in the period of liberalisation following the 1980 Coup), the work was first published as a feuilleton in the political journal Özgür Gelecek issued by Mehmet Bayrak. Owing to this publication, the issues of the journal were banned. Later, Mehmet Bayrak founded the publishing house Özge which published the entirety of Ağa, Şeyh, Devlet-Kürdistanın Sosyal ve Politik Örgütlenmesi (1991) as well as works on the Kurds by the American researcher Robert Olson (1992) and the Russian one Lazarev (2001). It also published one of Thomas Bois's books in 1991. Apart the publication of Martin Van Bruinessen's Kürdistan Üzerine Yazılar (1992), the well-established leftist publishing house Illetişim ${ }^{56}$ started to publish works on Kurds produced by European academics, such as Wadie Jwaideh (1999) or Lale Yalçın-Heckman (2002), much later, by the end of the decade. Another Kurdist publishing house that distinguished itself in the last half of the 1990s by publishing these European academic works was the Avesta publishing house that also owns a collection of kürdoloji. Through the contacts it established in Europe -- and mainly with the centres involved in promoting Kurdish studies such as the Kurdish institute in Paris -- this publishing house does a lot to publish the work of European academics in Turkish. These works are evidently read both by the Kurdish and Kurdist readership and by Turkish academics sensitive to the issue. Those publishing houses and independent researchers were often the first people in Turkey that Western academics met when they did fieldwork in the country as it was difficult to build ties. Then they played a major role in both producing works on Kurds and distributing those which were produced outside the country.

[66] 'Who writes about the Kurdish problem'? asked Duygu Köksal in 1997 in her review of Kirişçi and Winrow's newly published book ${ }^{57}$. Journalists, Western academia, Kurdish intellectuals and scholars, she answers. Journalists, whose position seems 'objective and distant', are interested in 'action, emotion and surprise' and often 'simplify the issue' (Köksal 1997: 174). We should add that journalists also very often took a position in the conflict. According to Köksal, Western academia tends either to 'perceive the problem in term of realpolitik' or to stick to the position of the 'righteous Western

56 Though it is not a university's publishing house, it is led by academics and known to publish many books by Turkish and Foreign academics.

57 Köksal, Duygu (1997) 'Who Writes about the Kurdish Problem (review article)', New Perspectives on Turkey 17, pp. 174-80. Review of Kirişçi, Kemal, Winrow, Gareth (1997) Kürt Sorunu, Kökeni ve Gelişimi, Tarih Vakfı Yurt Yayinları, Istanbul [translation of The Kurdish Question and Turkey. An Example of a Transstate Ethnic Conflict, London, Frank Cass. Note that the term 'ethnic conflict' does not appear in the translation in Turkish. 
Scalbert-Yücel, Clémence and Ray, Marie Le (2006) 'Knowledge, ideology and power. Deconstructing Kurdish Studies', European Journal of Turkish Studies, Thematic Issue N ${ }^{\circ} 5$, Power, ideology, knowledge deconstructing Kurdish Studies, URL : http://www.ejts.org/document777.html To quote a passage, use paragraph (§).

observer'. While one is too cold and pragmatic, the other falls into 'an a-historical representation of an anti-democratic country' (Köksal 1997: 174). Kurdish intellectuals and scholars' writings 'range from the radically militant and dogmatic to the rather self critical and democratic'. 'Just like Turkish official (or even the popular) mentality [...] Kurdish nationalist writing on the issue is ridden with a-historical generalizations' (Köksal 1997: 174-5). According to Köksal again, Kirişçi and Winrow's book is 'perhaps the first attempt to bring about a comprehensive description and analysis of Turkey's Kurdish Problem by prominent scholars who are themselves based in Turkish society' (Köksal 1997: 175). The first point the author makes is to underline that writing on ethnicity is a political act anywhere; it is more political in Turkey, even if it is done by academics, since the ethnic dimension of the Kurds has always been hidden or denied by the state's official(s) (researchers). And, as Turkish scholars, they belong to this circle. Moreover they are both close to the Kurdish question - as living in Turkish society - and distant - by using theoretical concepts, questions and terminology relevant to an international academia (Köksal 1997: 175).

[67] We stated above that the political context, the work done by civil society's organisations and by the Kurdist movement were certainly conditions that enabled the academic field to become more open towards the Kurds. After Beşikçi's (1969b), Kirişçi and Winrow's work (1997), together with Ergil's (1995), is among the first works on the issue stressing the ethnic and conflict dimensions. However, even though they are conducted by Turkish scholars, they were both undertaken without support from the academy. Is the Turkish academic field evolving today toward a more open approach to this question, under what sorts of constraints, and with which resources and approaches?

The role of the university: still marginal?

[68] Most of the scholars who started working explicitly on 'Kurds' or the 'Kurdish question' seem to have been at least partly trained in foreign (mostly British and American) universities. This seems to have led them to new objects of research and to new theories and approaches. Moreover, as Zeynep Gambetti states, the mere fact of being outside Turkey provided researchers with opportunities and spaces to talk freely about Kurds and to become aware of the issues surrounding them at a time when Turkish university was 'like a desert' (Gambetti 2006). The stay outside the Turkish university also enables the students to write their $\mathrm{PhD}$ on this issue. The return of young scholars from abroad finding 
Scalbert-Yücel, Clémence and Ray, Marie Le (2006) 'Knowledge, ideology and power. Deconstructing Kurdish Studies', European Journal of Turkish Studies, Thematic Issue N ${ }^{\circ} 5$, Power, ideology, knowledge deconstructing Kurdish Studies, URL : http://www.ejts.org/document777.html To quote a passage, use paragraph (§).

employment within Turkish universities may help to diversify approaches and profiles within universities. Yet discussing Kurdishness and the conflict does seem to be limited to only a handful of universities, the main ones being private.

[69] A working group has been founded within the public Boğaziçi University which was led by a political scientist, Zeynep Gambetti and by an economist, Şemsa Özar. Entitled '(Trans)formation of Conflict: Changing Power Configurations and Path to Democracy in South-eastern Turkey' it was a two-years trans-disciplinary project funded by the university. At a period marked by the ceasefire, by the end of the military conflict and by the 'democratisation studies' (as represented by Ergil) and 'conflict resolution studies' (as in the lectures program at Sabanci University led by Ayşe Betül Çelik), the project aimed at providing new approaches to the definition and the study of the conflict. They focus more on the transformation than on the end of the conflict. Leaving mainstream political sciences' works (as represented by Kirişçi and Winrow's Kurdish Question), they decided to undertake in-depth sociological fieldworks on a small scale and about microphenomenon (Gambetti 2006).

[70] Except for this one state university, research is led by private schools, mainly by Bilgi University through its Centre for Research and Implementation of Studies on Migration (Göç Çalışmaları Uygulama ve Araştırma Merkezi) founded in 2002 and by Koç University through its Migration Research Program (Mirekoç), founded in 2004 in collaboration with the Foundation for Population, Migration and Environment (Zurich). Those two centres work indirectly on Kurdish issue through the study of International Displaced Persons (IDP). Half of the eight projects backed by Mirekoç in 2006-2007 deals with the IDPs in Turkey; Bilgi's Migration Centres, following works on Assyrians, Gypsies and migrants from the East in Istanbul, has launched a project, funded by the Scientific and Technical Research Council of Turkey (Türkiye Bilimsel ve Teknik Araştırma Kurumu, TÜBITAK) ${ }^{58}$, entitled Internal Displaced in Turkey today: Integration or Return? (Günümüz Türkiye'sinde Yaşanan İç Göçler: Bütünleşme mi, Geri Dönüş mü?). None use the term 'Kurds' in their titles, but they do openly deal with them. Closely related to the issue of the internal displaced persons are questions of poverty and social exclusion, an area of study often combined to in-depth fieldwork in the main Turkish metropolis and in the southeast. promote an applied research. It determines researches priority and gives grants for research and fellowships. 
Scalbert-Yücel, Clémence and Ray, Marie Le (2006) 'Knowledge, ideology and power. Deconstructing Kurdish Studies', European Journal of Turkish Studies, Thematic Issue N ${ }^{\circ} 5$, Power, ideology, knowledge deconstructing Kurdish Studies, URL : http://www.ejts.org/document777.html To quote a passage, use paragraph (§).

The Social Policy Forum of the Boğaziçi University does a great deal of work on this issue (with Çağdaş Keyler, Nazan Üstündağ, Ayşe Buğra, and so on).

[71] These timely issues are attractive and much studied. They are also issues that greatly interest international organisations (such as the European Commission) and are initiated or backed by them. When initiated by them, they also often aimed at policymaking. The expert works often end with a 'report' including recommendations and policy proposals ${ }^{59}$. Moreover the influence of the think-tanks is growing and seems determinant in the orientations and the aims of research. The Turkish Economic and Social Studies Foundation (TESEV), a private think-tank, founded in 1994, was created in order to promote applied policy related research and 'forms a bridge between academic research and the policy making process' 60 . Works on minority rights, multiculturalism and displaced persons are undertaken within TESEV's democratisation program - which is clearly linked to the process of European Integration. The objectives of the program are to undertake research on the obstacles to a democratic society and state and to formulate policy proposals. IDPs are the main issue within the scope of which Kurdish issue is, sometimes very indirectly, studied (Aker, Çelik, Kurban, Ünalan, Yükseker 2005 and 2006). Indeed, as Nazan Üstündağ states: 'Kurdish displaced peoples are considered by authorities, NGO's and academicians alike as composing the third wave of migration in Turkey, and are distinguished from former migrants only in terms of their higher levels of poverty and 'ignorance' of urban ways. Once they enter the urban realm, they become part of a larger narrative of development and world capitalism where the specific violations they endured and the main problems that caused their 'migration' become hidden and go unregistered. When displaced populations are studied, it is usually their conditions, problems and the ways in which their immediate survival is secured what gains most attention' (Üstündağ 2004).

[72] Only few works examines actual Kurdish narratives (Üstündağ 2004) or specific forms of political and identity mobilisations (Çelik 2005) and then take into account the ethnic dimension of the issue. The demands from funding institutions can also be one of the factors hiding this dimension.

\footnotetext{
59 It was already the case for Kirisçi and Winrow's book which has been granted a fellowship of the United State Peace Institute and whose chapter 7 elaborates solutions to the problem.

60 See http://www.tesev.org.tr/
} 
Scalbert-Yücel, Clémence and Ray, Marie Le (2006) 'Knowledge, ideology and power. Deconstructing Kurdish Studies', European Journal of Turkish Studies, Thematic Issue N ${ }^{\circ} 5$, Power, ideology, knowledge deconstructing Kurdish Studies, URL : http://www.ejts.org/document777.html To quote a passage, use paragraph (§).

[73] Except very few collective research projects and more numerous individual researches, we can see that 'independent' research focusing on Kurds and stressing the conflict and its ethnic dimension is still rare in the Turkish academia. The research seems to be strongly orientated by the sponsoring organisations which are more interested in applied research related to a national and international focus. The weight of the sponsor organisation is also important due to the economic condition of the researcher in Turkey, where academics often need to turn towards private funding to finance his/her research. Between an applied and a committed research, the distinctive border is not always very clear. It is indeed common to see these scholars, involved in applied research, ending up joining social (sometimes political) activism in the concerned area (women, poverty alleviation, civil society), when they did not even come to the research through previous activism. For many of them, it is a moral duty, not only to make their works available to the general public, but also to contribute, if not through the implementation of public policies, to linked civil initiatives (see Gambetti 2006 and Van Bruinessen 2006).

[74] Moreover, constraints which weigh down the freedom of the scholar are still very strong. Except few Universities in Istanbul (most of them being private universities) and a very thin opening in some southeastern universities, no works can be (or are) conducted yet. Until today, no university has published a work on 'Kurds' or on 'the Kurdish issue'. The recent publication of the special issue of New Perspectives on Turkey (32, 2005) on the 'Kurdish question' is a collection of some Turkish scholars' works but it was published by a non-academic publishing house. Scholars are still put on trial for expressing the country's ethnic diversity61. University staff and rectors are still slandered62. Until today no university has published a work on 'Kurds' or on 'Kurdish issue'. The practice of autocensorship still remains ${ }^{63}$ and it seems that authors still prefer to publish in English and in international journals better read by foreign academic readerships than by Turkish citizens or scholars 64 .

61 Case of the sociologist Pınar Selek arrested in 1998, case of Baskın Oran. Look at Munoz (1998).

62 Başgöz, Illhan, 'Van'da Neler Gördüm, Neler Duydum?', Radikal, February 5, 2006.

63 In order to avoid legal problems, Gareth Winrow, co-author of the Kurdish question in Turkey with Kemal Kirisçi, submitted the book to the Interior Ministry prior to its publication. Gareth Winrow quoted by Munoz (1998).

64 Fulya Atacan's work on Kurdish Nurcu movement (2001), for example, has never been published in Turkish. 
Scalbert-Yücel, Clémence and Ray, Marie Le (2006) 'Knowledge, ideology and power. Deconstructing Kurdish Studies', European Journal of Turkish Studies, Thematic Issue N5, Power, ideology, knowledge deconstructing Kurdish Studies, URL : http://www.ejts.org/document777.html To quote a passage, use paragraph (§).

\section{Conclusion}

[75] Because of the very high degree of sensitivity of the issue, Kurdish studies has been shaped and evolved as a complex and fragmented field where scientific issues have constantly intersected with political ones. Since the existence of Kurds was mostly denied by the relevant states in the $20^{\text {th }}$ century, the definition of the object of these studies as 'Kurds', as well as the very construction of 'Kurdish studies' are loaded with political stakes, which invites the researchers to a necessary retrospective analysis. These political stakes certainly explain why mostly non-academic Kurdish centres get involved in fostering 'Kurdish studies'v and in gathering academics working on Kurds around them. Within Soviet academia, the opening of Kurdish departments was also certainly tied to the Soviet nationality policy. Even within Western academia, it is under the leadership of committed researchers that Kurdish studies have progressively but lately gained their autonomy from Turkish and Iranian studies.

[76] As exposed, Kurdish studies are also fragmented in space and have developed within different national frames and with diverse constraints and resources available. Interestingly, the circulation between these different spaces produces specific resources, especially useful for actors working in (highly) restrictive political environments. These resources include publications outside the country when a publication inside it would systematically be forbidden and drag along (at least) prosecutions. The translation and publication of foreign works within the country also have greatly contributed to impulse the debate. Besides, students fulfilling their master or $\mathrm{PhD}$ degrees overseas are often coming back to the country somewhat freed from the nationalist framing of the Kurdish question, conversant with the 'acceptable' international academic language and often integrated in valuable networks for publishing. In this sense, the scattering of knowledge production together with the circulation of knowledge's producers on different spaces is a resource in itself and contributes to the emergence of a debate even in less conducive environments. However, it still demands a minimal political opening or powerful alliances, possibly with political and/or business networks.

[77] In Turkey today, the field of Kurdish studies is likewise fragmented. There is no formalised Kurdish studies as such and the research rather develops around small units of scholars. These scholars come together but rather within their own university. They are perfectly abreast of foreign publications, but only slowly becoming aware of what is 
Scalbert-Yücel, Clémence and Ray, Marie Le (2006) 'Knowledge, ideology and power. Deconstructing Kurdish Studies', European Journal of Turkish Studies, Thematic Issue N ${ }^{\circ} 5$, Power, ideology, knowledge deconstructing Kurdish Studies, URL : http://www.ejts.org/document777.html To quote a passage, use paragraph (§).

happening in other Turkish universities. Interestingly enough, however, funding by international organisations or foreign research centres nurtures growing cooperation between these different groups of scholars, as well as with civil society representatives. The same funding mechanism, added to the transition through overseas universities, also contributes to a certain standardisation in the framing of the Kurdish question, as studies on 'democratisation' and 'empowerment of civil society', works on 'women', 'displaced people' but also on 'conflict resolution' are more specifically fostered. Two lines of differentiation tend to become apparent within the Turkish academic field today: one line between an 'old generation' of scholars very much influenced by a nationalist framing of the question, still holding down high positions within university, and a 'new generation' of scholars, most of whom have fulfilled part of their academic formation overseas and propose renewed, at least non-nationalist framings of the question. But a distinction should also be made within this 'new generation', with regard to approaches and practices of research, between what would be a macro/classical political science perspective asking the question of global democratisation and right to self-determination for example, and a more micro/socially-oriented perspective, giving value to in-depth fieldwork.

[78] In fact, asking the question in terms of economic backwardness, poverty alleviation, social changes or migrations, as it is done today, is not so much a re-framing of the question in itself. It presents striking similarities with what has been done from the 1960s on in studies talking about Kurds without naming them, or avoiding to focus on ethnic or national issues to remain acceptable in a specific political and ideological environment. Kurdish intellectuals themselves were, in the 1960s and 1970s, very much influenced by the mainstream analytic frame of economic development and social inequality. These recent studies may thus not be very directly disturbing for the state ideology and they do accommodate the self-censorship many universities still practice, but they nonetheless often contribute to deconstruct power mechanisms there. The positions of these scholars towards public and political authorities are also interestingly diverse. While some of them strive to make themselves heard from these authorities, possibly sacrificing some academic demands in the name of the exigency of the question, many choose to combine socially-oriented studies with 'civil' activism on the field. These studies however globally keep appealing to public policy shaping, somewhat like the studies achieved in the 1960s and 1970s did. 
Scalbert-Yücel, Clémence and Ray, Marie Le (2006) 'Knowledge, ideology and power. Deconstructing Kurdish Studies', European Journal of Turkish Studies, Thematic Issue N5, Power, ideology, knowledge deconstructing Kurdish Studies, URL : http://www.ejts.org/document777.html To quote a passage, use paragraph (§).

\section{References}

Akbulut, IIhan (1990) Devlet, Terörizm ve Ülke Bölücülüğü (Devlet içinde çeşitli Açılardan Terörizm ile Ülke Bölücülüğü Suçu), Istanbul, Boğaziçi Yayınları.

Aker, Tamer; Çelik, Ayşe Betül; Kurban, Dilek; Ünalan, Turgay; Yükseker, H. Deniz (2005) Rapor: Türkiye'de Ülke İçinde Yerinden Edilme Sorunu: Tespitler ve Çözüm Önerileri, Istanbul, TESEV. URL: http://www.tesev.org.tr/etkinlik/TESEV_UYE_Grubu_Raporu.pdf

Aker, Tamer; Çelik, Ayşe Betül; Kurban, Dilek; Ünalan, Turgay; Yükseker, H. Deniz (2006) 'Zorunlu Göç' ile Yüzleşmek: Turkiye'de Yerinden Edilme Sonrası Vatandaşı̆̆ın Inşası, Istanbul, TESEV Yayınları.

Aktay,Yaşın (2003) 'Üniversiteden Multiversiteye Taşra-Merkez Diyalektiği', Toplum ve Bilim 97, pp. 93-122.

Alakom Rohat (1991) [1987], Kürdoloji Biliminin 200 Yıllık Geçmişi (1787-1987), Istanbul, Deng.

Alavi, H. (1973) 'Peasant Classes and Primordial Loyalties', Journal of Peasant Studies I/1, pp. 23-62.

Andrews, Peter Alford (2002) [1989] Ethnic Groups in the Republic of Turkey, Wiesbaden, L. Reichert.

Arslan, Ali (2004) Kısır Döngü Türkiye'de Üniversite ve Siyaset, Istanbul, Truva.

Atacan, Fulya (2001) 'A Kurdish Islamist Group in Modern Turkey: Shifting Identities', Middle Eastern Studies 37 (3), p. 111-144.

Ayata, Bilgin; Yükseker, Deniz (2005) 'A Belated Awakening: National and International Responses to the Internal Displacement of Kurds in Turkey', New Perspectives on Turkey 32, pp. 5-42.

Aydın, Delal (2005) Mobilizing Kurds in Turkey: Newroz as a Myth, Msc Thesis, Department of Sociology, Middle East Technical University Ankara, Ankara (supervised by Mesut Yeğen).

Barth, Frederik (1953) Principles of Social Organisation in Southern Kurdistan, Oslo, Universitetets Etnografiske Museum.

Barth, Frederik (2001) Kurdistan'da Toplumsal Örgütlenmenin IIlkeleri, Istanbul, Avesta.

Barthold, V. V. (1947) La découverte de l'Asie Histoire de l'orientalisme en Europe et en Russie, Paris, Payot (translated from Russian by Basile Nikitine).

Başgöz, IIhan (1972) 'Folklore Studies and Nationalism in Turkey', in Oinas, Felix J. (ed.), Folklore, Nationalism and Politics, Colombus, Ohio, Indiana University Folklore Institute, Monograph Series, Slavia Publishers INC, vol. 30, pp. 123-137.

Baumann, Zygmunt (1987) Legislators and Interpreters: on Modernity, Postmodernity and Intellectuals, Cambridge, Polity Press.

Bayrak, Mehmet (1993) Kürtler ve Ulusal-Demokratik Mücadeleri, Ankara, Özge.

Bayrak, Mehmet (1994), Kürdoloji Belgeleri, Ankara, Özge.

Bayrak, Mehmet (2004) Kürdoloji Belgeleri II, Ankara, Özge.

Bedirkhan, Celadet Ali (1997) [1934] De la question kurde/Kürt Sorunu üzerine, Istanbul, Avesta.

Bedirkhan, Kamuran Ali (1959), La question kurde, Paris.

Béhar, David (2002) 'Les universités privées d'Istanbul', Les dossiers de l'IFEA, Série la Turquie aujourd'hui, $n^{\circ} 10$, Istanbul, IFEA/OUI.

Belge, Taciser (1992) Kürt Sorunu için Barış İnisyatifi, Helsinki Yurtaşlar Meclisi Türkiye Milliyetler komitesi.

Benningsen, Alexandre (1960) 'Les Kurdes et la kurdologie en Union Soviétique', Cahiers du Monde russe et soviétique, vol. 1-2, pp. 513-530. 
Scalbert-Yücel, Clémence and Ray, Marie Le (2006) 'Knowledge, ideology and power. Deconstructing Kurdish Studies', European Journal of Turkish Studies, Thematic Issue N ${ }^{\circ} 5$, Power, ideology, knowledge deconstructing Kurdish Studies, URL : http://www.ejts.org/document777.html To quote a passage, use paragraph (§).

Berksöy, Biriz (2000) Party Conferences 1935-45: Academia's Contribution to Ideological mobilization in Turkey, Master Thesis, Istanbul, Boğaziçi University.

Bertrand, Frédéric (2005) 'N. Marr et le Marrisme dans l'ethnographie soviétique des années 1920-1930', Cahiers de l'ILSL 20, pp. 27-38.

Bertrand Romain (2006) 'Les orientalistes, conseillers du prince colonial? Expertise savante et 'politique musulmane' aux Indes néerlandaises (c. 1880-1920)', Raisons politiques 22, pp. 95-117.

Beşikçi, İsmail (1969a) Doğu'da Değişim ve Yapısal Sorunlar (Göçebe Alikan Aşireti), Ankara, Sevinç Matbaası.

Beşikçi, İsmail (1969b) Doğu Anadolu'nun Düzeni: Sosyo/ekonomik ve Etnik Temeller, Ankara, E Yayınları. Republishing in 1992 by Yurt Yayınları.

Beşikçi, İsmail (1977a) Kürtlerin 'mecburi iskânı', Ankara, Komal.

Beşikçi, İsmail (1977b) Türk-tarih tezi', 'Güneş-dil teorisi' ve Kürt sorunu, Ankara, Komal.

Beşikçi, İsmail (1978) Cumhuriyet Halk Fırkası'nın Tüzüğü (1927) ve Kürt Sorunu, Ankara, Komal.

Beşikçi, İsmail (1988) 'Doğu Anadolu'nun Düzeni'nin Başına Gelenler', Sosyalizm ve Toplumsal Mücadeleler Ansiklopedisi, Istanbul, İletişim, vol. 7, pp. 2124-2125.

Beşikçi, İsmail (1990a) Devletlerarası Sömürge Kurdistan/Bilim Resmi Ideoloji -Devlet Demokrasi ve Kürt Sorunu, Paris, Institut Kurde de Paris.

Beşikçi, İsmail (1990b) Tunceli Kanunu (1935) ve Dersim Jenosidi, Istanbul, Belge.

Beşikçi İsmail (1991a) Bilim Yöntemi, Ankara, Yurt.

Beşikçi, İsmail (1991b) Cumhuriyet Halk Fırkası'nın Programı (1931) ve Kürt sorunu, Istanbul, Belge.

Beşikçi, İsmail (1991c) Devletlerarası Sömürge Kürdistan, Ankara, Yurt-Kitap.

Beşikçi, İsmail (1991d) Orgeneral Muğlalı olayı: otuzüç kurşun, Istanbul, Belge.

Beşikçi, İsmail (1992a) Doğu Mitingleri'nin Analizi (1967), Ankara, Yurt Kitap.

Beşikçi, İsmail (1992b) Kürdistan Üzerinde Emperyalist Bölüşüm Mücadelesi 1915-1925,

Ankara, Yurt Kitap-Yayın.

Beşikçi, İsmail (1993) Kürt Toplumu Üzerine, Istanbul, Yurt-Kitap.

Beşikçi, İsmail (1996) Hayali Kürdistan'ın Dirilişi, Istanbul, Aram.

Birikim (2001) 'Bilgi Çağı Eşiğinde Üniversiteler' 142-143 (special issue).

Blau, Joyce (1986) 'Qanatê Kurdoev (1909-1985)', Studia Iranica 15 (2), pp. 249-256.

Blau, Joyce (et alii) (1989) Les Kurdes et le Kurdistan Bibliographie critique 1977-1986, Abstracta Iranica, hors série $n^{\circ} 5$, Téhéran-Paris, IFRI.

Blau, Joyce (1995) 'Kurde', in Labrousse, Pierre (ed.), Langues'O 1795-1995 Deux siècles d'histoire de l'Ecole des langues orientales, Paris, Hervas, pp. 96-98.

Blau, Joyce (1996) 'La Réforme de la langue kurde' in Fodor, Istvan; Hagège, Claude (eds.), La réforme des langues, Hamburg, Buske Verlag, tome 4, pp. 63-85.

Blau, Joyce (2006) 'Une perspective historique sur les études kurdes. Entretien avec Joyce Blau', European Journal of Turkish Studies, Thematic Issue $\mathrm{N}^{\circ} 5$, Power, ideology, knowledge - deconstructing Kurdish Studies, URL : http://www.ejts.org/document797.html

Bletch, Chirguh (1930) La Question Kurde, Le Caire, Publication de la Ligue Nationale Kurde Hoybun, Imprimerie P. Barbey.

Bois, Thomas (1946) 'L'âme des Kurdes à la lumière de leur folklore', Cahier de l'Est 5-6.

Bois, Thomas (1963a) 'De la langue à l'âme du peuple kurde : l'apport philologique, folklore, éléments de sociologie kurde', Bibliotheca Orientalist 20 (1-2), pp. 6-9.

Bois, Thomas (1963b) 'Les dominicains à l'avant-garde de la kurdologie au XVIII ${ }^{\circ}$ siècle', Archivum Fratrum Praedicatorum 35, pp. 265-292.

Bois, Thomas (1965) Connaissance des Kurdes, Beyrouth, Khayats. 
Scalbert-Yücel, Clémence and Ray, Marie Le (2006) 'Knowledge, ideology and power. Deconstructing Kurdish Studies', European Journal of Turkish Studies, Thematic Issue N ${ }^{\circ} 5$, Power, ideology, knowledge deconstructing Kurdish Studies, URL : http://www.ejts.org/document777.html To quote a passage, use paragraph (§).

Bois, Thomas (1991) Folklorları Işığında Kürtlerin Ruhu, Ankara, Özge.

Bora, Tanıl; Can, Kemal (1994) [1991] Devlet, Ocak, Dergâh. 12 Eylül'den 1990'lara Ülkücü Hareket, Istanbul, İletişim.

Bora, Tanıl; Can, Kemal (2000) 'MHP'nin Güç Kaynağı Olarak Kürt Meselesi', Birikim 134135, pp. 56-72.

Bourdieu, Pierre (1984) Homo academicus, Paris, Minuit.

Bozarslan, Hamit (1991), 'Tribus, confréries et intellectuels : convergence des réponses kurdes au Kémalisme', in Vaner, Semih (ed.), Modernisation autoritaire en Turquie et en Iran, Paris, L'Harmattan, pp. 61-80.

Bozarslan, Hamit (1993) 'La régionalisation du problème kurde', in Picard, Elizabeth (ed.), La nouvelle dynamique au Moyen-Orient. Les relations entre l'orient arabe et la Turquie, Paris, L'Harmattan, pp. 174-191.

Bozarslan, Hamit (1994) 'États et mode de gestion du problème kurde', Peuples méditerranéens 68-69, pp.185-214.

Bozarslan, Hamit (1997) La question kurde. États et minorités au Moyen-Orient, Paris, Presses de Sciences Po.

Bozarslan, Hamit (2000) 'Research Guide: Kurdish Studies', MERIA News 3, URL: http://meria.idc.ac.il/news/2000/00news3.html\#Kurds

Bozarslan, Hamit (2001) 'Quelques remarques sur le discours historiographique kurde en Turquie : 1918-1980', Asien Afrika Latinamerika 29, pp. 47-71.

Bozarslan, Hamit (2004) Histoire de la Turquie contemporaine, Paris, La découverte.

Bozarslan, Hamit (2006) 'Rompre avec l'hypothèse d'une singularité kurde. Entretien avec Hamit Bozarslan', European Journal of Turkish Studies, Thematic Issue $\mathrm{N}^{\circ} 5$, Power, ideology, knowledge - deconstructing Kurdish Studies, URL : http://www.ejts.org/document761.html

Bozarslan, Mehmet Emin (2002) [1966] Doğu'nun Sorunları, Istanbul, Avesta.

Cardıcı, Musa; Süslü, Azmi (1982) Ankara Üniversitesi Gelişim Tarihi, Ankara.

Chaliand, Gérard (1979) Les Kurdes et le Kurdistan. La question nationale kurde au Proche Orient, Paris, Maspéro.

Cizre, Ümit (1996) 'Historicizing the Present and Problematizing the Future of the Kurdish Problem: a Critique of the TOBB Report on the Eastern Question', New Perspectives on Turkey 14, pp. 1-22.

Copeaux, Etienne (1997) Espaces et temps de la nation turque: analyse d'une historiographie nationaliste - 1931-1993, Paris, CNRS.

Cwiklinski, Sebastian (2004-5) 'Die Geschichte der Kurdologie im Zaristichen Russland bis 1917', Kurdische Studien 4-5, pp. 238-242.

Çay, Abdülhaluk (1985) Türk Ergenekon Bayramı Nevruz, Ankara, TKAE.

Çelik, Ayşe Betül (2005) 'I miss my village!': Forced Kurdish migrants in Istanbul and theirs representations in associations', New Perspectives on Turkey 32, pp. 137-163.

Donegani, Jean Marie (2006) 'De l'anthropologie au politique', Raisons Politiques 22, pp. 5-14.

Dorronsoro, Gilles (2006) 'Les politiques ottomane et républicaine au Kurdistan à partir de la comparaison des milices Hamidiye et korucu: modèles institutionnels, retribalisation et dynamique des conflits', European Journal of Turkish Studies, Thematic Issue $N^{\circ} 5$, Power, ideology, knowledge - deconstructing Kurdish Studies, URL : http://www.ejts.org/document778.html

Dündar, Fuat (1999) Türkiye Nüfus Sayımlarında Azınlıklar, Istanbul, Çiviyazıları Yayınları. Dündar, Fuat (2001) ittihat ve Terakki'nin Müslümanları İskân Politikası, Istanbul, İletişim. 
Scalbert-Yücel, Clémence and Ray, Marie Le (2006) 'Knowledge, ideology and power. Deconstructing Kurdish Studies', European Journal of Turkish Studies, Thematic Issue N ${ }^{\circ} 5$, Power, ideology, knowledge deconstructing Kurdish Studies, URL : http://www.ejts.org/document777.html To quote a passage, use paragraph (§).

Dündar, Fuat (2006a) 'La fondation de la kurdologie turque et Ziya Gökalp', European Journal of Turkish Studies, Thematic Issue $\mathrm{N}^{\circ} 5$, Power, ideology, knowledge deconstructing Kurdish Studies, URL : http://www.ejts.org/document772.html

Dündar, Fuat (2006b) L'ingénierie ethnique du Comité Union et Progrès et la turcisation de l'Anatolie (1913-1918), Thèse de Doctorat d'Histoire, Ecole des Hautes Etudes en Sciences Sociales, Paris (sous la direction de Hamit Bozarslan).

Ergil, Doğu (1995) Doğu Sorunu. Teşhisler ve Tesbitter, Özel Araştırma Raporu. Istanbul, Stratejik Araştırma Dizisi, $n^{\circ} 1$.

Ergil, Doğu (2006a) 'Knowledge is a potent instrument for change'. Interview with Doğu Ergil', European Journal of Turkish Studies, Thematic Issue N ${ }^{\circ} 5$, Power, ideology, knowledge - deconstructing Kurdish Studies, URL : http://www.ejts.org/document762.html Ergil, Doğu (2006) 'Results of a survey conducted in 2005 on democracy in Turkey', European Journal of Turkish Studies, Thematic Issue $\mathrm{N}^{\circ} 5$, Power, ideology, knowledge deconstructing Kurdish Studies, URL : http://www.ejts.org/document769.html

Erichsen, Régine (1998) 'Scientific Research and Science Policy in Turkey' CEMOTI 25, pp. 197-228. URL: http://cemoti.revues.org/document61.html

Eröz, Mehmet (1975) Doğu Anadolu'nun Türklüğü, Istanbul, Türk Kültürü Yayın.

Ersanlı-Behar, Büşra (1992) İktidar ve Tarih. Türkiye'de 'Resmi Tarih' Tezinin Oluşumu (1929-1937), Istanbul, Afa.

Fırat, M. Şerif (1961) [1949] Doğu IIlleri ve Varto Tarihi, Ankara, Milli Eğitim Basımevi.

Foucault, Michel (2003) [1966] Les mots et les choses. Une archéologie des sciences humaines, Paris, Gallimard.

Foucault, Michel (1980) Power / knowledge: Selected Interviews and others writings (19727), London, Harvester Press.

Gambetti, Zeynep (2005) 'The conflictual (trans)formation of the public sphere in urban space: the case of Diyarbakır', New perspectives on Turkey 32, pp. 43-71.

Gambetti, Zeynep (2006) 'The search for a new ground. Interview with Zeynep Gambetti', European Journal of Turkish Studies, Thematic Issue N ${ }^{\circ} 5$, Power, ideology, knowledge deconstructing Kurdish Studies, URL : http://www.ejts.org/document784.html

Garzoni, Maurizio (1787) Grammatica e vocabullario della lingua kurda, Roma.

Goujon, Alexandra (2006) 'Anthropologie et gestion des nationalités en Russie', Raisons politiques (22), pp. 73-94.

Gökalp, Ziya (1992) Kürt Aşiretleri Hakkında Sosyolojik Tetkikler, Istanbul, Sosyal.

Groc, Gérard (1998) 'La 'société civile' turque entre politique et individu', CEMOTI 26, pp. 43-74. URL: http://cemoti.revues.org/document129.html

Gündoğan, Azat Zana (2005) The Kurdish Political Mobilization in the 1960s: The Case of 'the Eastern Meetings', Msc Thesis, Department of Sociology, Middle East Technical University, Ankara.

Hirschler, K. (2001) 'Defining the Nation: Kurdish Historiography in Turkey in the 1990s', Middle Eastern Studies 37 (3), pp. 145-166.

Howell, Wilson N. (1965) The Soviet Union and the Kurds. A Study of National Minority Problems in Soviet Policy, Doctorate thesis, University of Virginia.

Izady, Mehrad R. (1992) The Kurds: A Concise Handbook, London, Taylor and Francis.

Izady, Mehrad R. (2004) Kürtler, Istanbul, Doz.

Illhan, Suat (1998) Terör Neden Türkiye, Ankara, Nu-do.

Jîn, Uppsala, Deng, 1985 [New edition prepared by M. E. Bozarslan]. Jwaideh, Wadie (1999) Kürt Milliyetçiliğinin Tarihi Kökenleri ve Gelişimi, Istanbul, Illetişim. Kafesoğlu, İbrahim (1968) 'Türkiye'de İlmi Millileştirme', Türk Kültürü 65, pp 274-277 
Scalbert-Yücel, Clémence and Ray, Marie Le (2006) 'Knowledge, ideology and power. Deconstructing Kurdish Studies', European Journal of Turkish Studies, Thematic Issue N ${ }^{\circ} 5$, Power, ideology, knowledge deconstructing Kurdish Studies, URL : http://www.ejts.org/document777.html To quote a passage, use paragraph (§).

Karapınar, Barış (2005) 'Land Inequality in Rural Southeastern Turkey: Rethinking Agricultural Development', New Perspectives on Turkey 32, p. 125-197.

Kırzıoğlu, M. Fahrettin (1995) [1968], Kürtlerin Türklüğün, Istanbul, Hamle.

Kirişci, Kemal; Winrow, Gareth (1997) The Kurdish Question and Turkey. An Example of a Trans-state Ethnic Conflict, London, Portland, Frank Cass.

Kirişçi, Kemal; Winrow, Gareth (1997) Kürt Sorunu, Kökeni ve Gelişimi, Istanbul, Tarih Vakfı Yurt Yayınları.

Koçak, Cemil (2003) Umûmî Müfettişlikler (1927-1952), Istanbul, Illetişim.

Kop, Kadri Kemal (1982) [1935] Araştırma ve Düşüncelerim. Doğu ve Güneydoğu Anadolu Türkçesini Etkileyen Faktörler, Ankara, TKAE.

Kop, Kadri Kemal (1982) [1938] Anadolu'nun Doğu ve Güneydoğusu, Ankara, TKAE.

Köksal, Duygu (1997) 'Who Writes about the Kurdish Problem (review article)', New Perspective on Turkey 17, pp. 174-80.

Kutschera, Chris (1979) Le mouvement national kurde, Paris, Flammarion.

Küçük, Yalçın (1990) Kürtler üzerine Tezler, Istanbul, Dönem.

Labrousse, Pierre (ed.) (1995) Langues'O 1795-1995. Deux siècles d'histoire de l'École des langues orientales, Paris, Hervas.

Landau, Jacob M. (1997) 'Arab and Turkish Universities: some Characteristics', Middle Eastern Studies 33 (1), pp. 1-19.

Landau Jacob M. (1995) [1981] Pan-Turkism From Irredentism to Cooperation, London, Hurst \& Compagny.

Lazarev, M. S. (2001) Emperyalizm ve Kürt Sorunu (1917-1923), Ankara, Özge.

Massicard, Élise (2003) 'Être pris dans le mouvement: savoir et engagement sur le terrain', Conflits et Cultures 47. URL: http://www.conflits.org/document838.html, http://www.conflits.org/document840.html

Meho, Lokman I. (1997) Kurds and Kurdistan A Selective and Annotated Bibliography, Westport, London, Greenwood Press.

Minorsky, Vladimir (1927) 'Kurdes', Encyclopédie de l'islam, Leiden, Paris, E. J. Brill, Picard, pp. 1196-1219.

Minorsky, Vladimir (1963) 'La Kurdologie et l'enseignement de la langue kurde en URSS', L'ethnologue 57, pp. 71-105.

Mokri, Muhammad (1963) 'Kurdologie et enseignement de la langue russe en URSS', L'ethnographie.

Monceau, Nicolas (2005) 'Les intellectuels mobilisés: le cas de la Fondation d'histoire de Turquie' in Dorronsoro, Gilles (ed.) La Turquie conteste, Paris, CNRS, pp. 109-126.

Munoz, Elisa (1998) Scientists clash with the State of Turkey: Four Case Studies, New York, American Association for the Advance of Science. URL: http://shr.aaas.org/scws/

New Perspectives on Turkey, Kurdish Question, ${ }^{\circ} 322005$.

Nikitine, Basile (1932) 'Où en est la Kurdologie?', Annali del Real Institute Orientale Del Napoli.

Nikitine, Basile (1956) Les Kurdes. Etude sociologique et historique, Paris, Imprimerie nationale, Bibliothèque $C$. Klincksieck.

Nikitine, Basile (1994) [1976] Kürtler Sosyolojik ve Tarihi Inceleme, Istanbul, Deng.

Olson, Robert (1992) Kürt Milliyetçiliğin Kaynakları ve Şeyh Said İsyanı, Ankara, Özge.

O'Shea, Maria T. (2004) Trapped Between the Map and the Reality. Geography and Perception of Kurdistan, London, Routledge.

Öncü, Ayşe (1987) 'Academics: the West in the Discourse of University Reform', in Herper, Metin; Öncü, Ayşe; Kramer, Heinz (eds.) Turkey and the West : Changing Political and Cultural Identities, London, New-York, IB Tauris, pp. 142-176. 
Scalbert-Yücel, Clémence and Ray, Marie Le (2006) 'Knowledge, ideology and power. Deconstructing Kurdish Studies', European Journal of Turkish Studies, Thematic Issue N ${ }^{\circ} 5$, Power, ideology, knowledge deconstructing Kurdish Studies, URL : http://www.ejts.org/document777.html To quote a passage, use paragraph (§).

Özer, Ahmet (1994) GAP ve Sosyal Değişme, Diyarbakır, Dicle Üniversitesi GAP Araşıırma ve Uygulama Merkezi Yayın, nº, DÜ Basımevi.

Özgen, Neşe (2003) Toplumsal Hafızanın Hatırlama ve Unutma Biçimleri Van-Özalp ve 33 Kurşun Olayı, Istanbul, Tüstav.

Özök-Gündoğan, Nilay (2005) 'Social development' as a Governmental Strategy in the Southeastern Anatolia Project', New Perspectives on Turkey 32, pp. 93-111.

Pradier, Jean Otton (1968) Les Kurdes, révolution silencieuse, Ducros, Bordeaux.

Pérouse, Jean-François (2005) 'Reposer la 'question kurde', in Vaner, Semih (ed.) La Turquie, Paris, Fayard-Ceri, pp. 357-387.

Picard, Elizabeth (ed.) (1991) La question kurde, Bruxelles, Complexe,.

Rondot, Pierre (1933) 'L'alphabet kurde en caractère latins d'Arménie soviétique', Revue des Etudes islamiques, cahier III, pp. 411-417.

Rondot, Pierre (1935) 'L'adoption des caractères latins et le mouvement culturel chez les Kurdes de l'URSS', Revue des études islamiques, cahier I, pp. 87-96.

Rödiger, E.; Pott, A. F. (1840) 'Kurdische Studien', Zeitschrift für die Kunde des Morgenlandes, vol. 3, p. 1-63.

Sakaoğlu, Necdet (1992) Cumhurriyet Döneminde Eğitim Tarihi, Istanbul, Iletişim.

Said, Edward (1980) L'orientalisme L'Orient créé par l'Occident, Paris, Le Seuil.

Scalbert-Yücel, Clémence (2006) 'Comment la langue kurde est devenue turque. Linguistique et dialectologie dans les universités turques', European Journal of Turkish Studies, Thematic Issue $\mathrm{N}^{\circ} 5$, Power, ideology, knowledge - deconstructing Kurdish Studies, URL : http://www.ejts.org/document771.html

Sekban, Chukru Mehmed (1933) La question kurde Des problèmes des minorités, Paris, PUF.

Selek, Pınar (2004) Barışamadık, Istanbul, İthaki.

Somersan, Semra (2004) Sosyal Bilimlerde Etnisite ve Irk, Istanbul, Istanbul Bilgi Üniversitesi Yayınları.

Somer, Murat (2005) 'Defensive vs Liberal-Nationalist Perspectives on Diversity and the Kurdish Conflict: Europeanization, the Internal Debate and Türkiyellik', New Perspectives on Turkey 32, pp.73-91.

Strohmeier, Martin (2003) Crucial Images in the Presentation of a Kurdish National Identity. Heroes and Patriots, Traitors and Foes, Leiden, Boston, Brill.

Şen, Leyla (2005) 'Poverty Alleviation, Conflict and Power in Poor Displaced Households: a Study of the Views of Women in Diyarbakır', New Perspectives on Turkey 32, pp. 113135.

Taşkın, Yüksel (2001a) 'Akademinin Medya ve Devletle Dansı', Birikim 142-143, pp. 70-76. Taşkın, Yükel (2001b) Intellectual and the State in Turkey: the Case of Nationalist Conservatism During and After the Cold War, Istanbul, PhD Thesis, Boğaziçi University.

Tejel, Jordi (2006) 'Les constructions de l'identité kurde sous l'influence de la 'connexion kurdo-française' au Levant (1930-1946)', European Journal of Turkish Studies, Thematic Issue $\mathrm{N}^{\circ} 5$, Power, ideology, knowledge - deconstructing Kurdish Studies, URL : http://www.ejts.org/document751.html

Tejel, Jordi (2007) Le mouvement kurde en exil. Continuités et discontinuités du nationalisme kurde sous le mandat français en Syrie et au Liban (1925-1946), Berne, Peter Lang.

Toplum ve Bilim (2003) 'Homo Academicus Alla Turca', 97.

Tuncay, Mete (1983) 'YÖK', Cumhurriyet Dönemi Türkiye Ansiklopedisi, vol. 3, Istanbul, İletişim, pp. 680-688.

Turgut, Mehmet (1996) 'Doğu Sorunu Raporu’ Üzerine, Istanbul, Boğaziçi Yayınları. 
Scalbert-Yücel, Clémence and Ray, Marie Le (2006) 'Knowledge, ideology and power. Deconstructing Kurdish Studies', European Journal of Turkish Studies, Thematic Issue N ${ }^{\circ} 5$, Power, ideology, knowledge deconstructing Kurdish Studies, URL : http://www.ejts.org/document777.html To quote a passage, use paragraph (§).

Torî (2001a) Kürtlerin Kökeni: Ari Boylardan Urartular, Istanbul, Istanbul Kürt Enstitüsü.

Torî (2001b) Kürt Sultan Selahaddin ve Eyyubi Hanedani, Istanbul, Istanbul Kürt Enstitüsü.

Resid, Tosinê (1983) 'Peşketina Kurdolojiyê li Akademiya Ermenistanê', Roja nû 2.

Reşid, Tosinê (1984) 'Kongra Kurdnasiyê ya Peşîn', Roja nû 6.

Üstündağ, Nazan (2004) 'The Construction of Witnessing Voices and the Representation of Violence and Loss', Paper presented at the Symposium 'The Stakes at Issue with Turkey's Application for Membership of the European Union' organised by the Kurdish Institute in Paris, Paris, October 2004. URL: http://www.institutkurde.org/en/conferences/the_stakes_at_issue_with_turkey_s_applicatio $\mathrm{n}$ _for_membership_of the european_union/Nazan+Ustundag.html

Üstündağ, Nazan (2005) Belonging to the Modern: Women's Suffering and Subjectivities in Urban Turkey, PhD Thesis, Bloomington, Indiana University.

Vali, Abbas (1996) 'Nationalism and Kurdish Historical writing', New Perspectives on Turkey 14, p. 23-51.

Vali, Abbas (ed.) (2003a) Essays on the Origins of Kurdish Nationalism, Costa Mesa, Mazda, 2003.

Vali, Abbas (ed.) (2003b) 'Genealogies of the Kurds: Constructions of Nation and National Identity in Kurdish Historical Writing', in Vali, Abbas (ed.), Essays on the Origins of Kurdish Nationalism, Costa Mesa, Mazda, pp. 58-107.

Vanly, Ismet Şerif (1970) Le Kurdistan irakien, entité nationale, Neuchatel, La Baconnière. Van Bruinessen, Martin (1991) Ağa, Şeyh, Devlet-Kürdistanın Sosyal ve Politik örgütlenmesi, Özge, Ankara.

Van Bruinessen, Martin (1992a) Agha, Shaikh and State. The Social and Political Structures of Kurdistan, London, Zed Books.

Van Bruinessen, Martin (1992b) Kürdistan Üzerine Yazılar, Istanbul, İletişim

Van Bruinessen, Martin (2000) Kürtlük, Türklük, Alevilik: Etnik ve Dinsel Kimlik Mücadeleleri, Istanbul, Illetişim.

Van Bruinessen, Martin (2003) Aga, Seyh, Devlet, Istanbul, Illetişim.

Van Bruinessen, Martin (2003-4) 'Ismail Beşikçi: Turkish Sociologist, Critic of Kemalism, and Kurdologist', The Journal of Kurdish Studies 5, pp. 19-34. URL: http://www.let.uu.nl/ martin.vanbruinessen/personal/publications/ismail_besikci.htm

Van Bruinessen, Martin (2006) 'I Would be Sitting in the Village Room where People Gather Interview with Martin Bruinessen', European Journal of Turkish Studies, Thematic Issue $\mathrm{N}^{\circ} 5$, Power, ideology, knowldege - deconstructing Kurdish Studies, URL : http://www.ejts.org/document775.html

Viennot, Jean-Pierre (1969) Contribution à l'étude du mouvement national kurde, Paris, thèse de doctorat d'histoire, Université de la Sorbonne.

Weber, Max (2005) [1959] Le savant et le politique, Paris, Plon, 10/18.

Williamson, Bill (1987) Education and Social Change in Egypt and Turkey A Study in Historical Sociology, London, Mac Millan Press.

Yalçın-Heckmann, Lale (2002) Kürtlerde Aşiret ve Akrabalık Iliş̧kileri, Istanbul, Iletişim.

Yavuz, M. Hakan (1999) 'Media Identity for Alevis and Kurds in Turkey', in Eickelman, Dale; Anderson, John (eds), New Medias in the Muslim World: the Emerging Public Sphere, Bloomington, Indiana University Press, pp. 180-199.

Yeğen, Mesut (1994) The Archeology of Republican Turkish State Discourse, unpublished PhD Thesis, Colchester, University of Essex.

Yeğen, Mesut (1996) 'The Turkish State Discourse and the Exclusion of Kurdish Identity', in Kedourie, S. (ed.) Turkey, Identity, Democracy, Politics, London, Portland, pp. 216-229. Yeğen, Mesut (1999) Devlet Söyleminde Kürt Sorunu, Istanbul, Iletişim. 
Scalbert-Yücel, Clémence and Ray, Marie Le (2006) 'Knowledge, ideology and power. Deconstructing Kurdish Studies', European Journal of Turkish Studies, Thematic Issue N${ }^{\circ} 5$, Power, ideology, knowledge deconstructing Kurdish Studies, URL : http://www.ejts.org/document777.html To quote a passage, use paragraph (§).

Zürcher, Erik J. (1998) 'The Rise and Fall of 'Modern Turkey'. URL: http://www.led.leidenuniv.nl/tcimo/tulp/Research/Lewis.htm

i In this text, 'Turkish scholars' or 'European academics' are not used in reference to the ethnic belonging of the researchers but in reference with the academic fields they evolve in. Then, there is no difference made here between either the Turkish and Kurdish scholars working in Turkey or the French and Kurdish scholars working in France for example. Nevertheless, we do acknowledge that this ethnic dimension may be another relevant criterion to think the changing features of academic spheres.

ii Version before 14.09.2007 update: 'It was written for the leftist public opinion that, generally, ignored the issue, which they saw as the most important remaining after the settlement of the colonial question'.

iii Version before 14.09.2007 update: 'The author acknowledges the existence of separate Kurdish questions within each state which he puts into comparison - the work words the division of the movements and of the Kurds within different countries, divisions which were, though not worded, perceptible in the shape of the previous works (Bozarslan 1997: 312)'.

iv Following a comment of Neşe Özgen, this paragraph has been modified. Version before 14.09.2007 update: 'Researchers like Neşe Özgen (a sociologist at the Aegean University), first conducted field work under the supervision of the GAP in 1997. When she was doing her survey for the GAP in 1997 in the İdil area (department of Şırnak) about 'development and local dynamics', new questions arose, the main one being 'what does it mean to be a citizen on the frontier'? She then decided to work as an independent university researcher in the south and southeast border regions and she developed what she calls a 'sociology of the frontier' (sınır sosyolojisi)'.

$\checkmark$ Version before 14.09.2007 update: 'These political stakes certainly explain why non-academic Kurdish centres mostly get involved in fostering 'Kurdish studies'. 